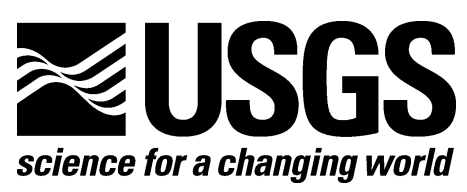

\title{
The Miocene Topanga Group of Southern California-A 100-Year History of Changes in Stratigraphic Nomenclature
}

By Russell H. Campbell, Thane H. McCulloh, and John G. Vedder

Open-File Report 2007-1385, Version 1.1, revised 2009

U.S. Department of the Interior

U.S. Geological Survey 


\title{
U.S. Department of the Interior \\ KEN SALAZAR, Secretary
}

\section{U.S. Geological Survey \\ Marcia K. McNutt Director}

\author{
U.S. Geological Survey, Reston, Virginia 2007 \\ Revised 2009
}

\author{
For product and ordering information: \\ World Wide Web: http://www.usgs.gov/pubprod/ \\ Telephone: 1-888-ASK-USGS
}

For more information on the USGS-the Federal source for science about the Earth, its natural and living resources, natural hazards, and the environment:

World Wide Web: http://www.usgs.gov/

Telephone: 1-888-ASK-USGS

Suggested citation:

Campbell, R.H., McCulloh, T.H., and Vedder, J.G., 2007, revised 2009, The Topanga

Group; a 100-year history of changes in stratigraphic nomenclature: U.S. Geological Survey, Open-File Report 2007-1385, version 1.1, 36 p.

[http://pubs.usgs.gov/of/2007/1385/].

Any use of trade, product, or firm names is for descriptive purposes only and does not imply endorsement by the U.S. Government.

Although this report is in the public domain, permission must be secured from the individual copyright owners to reproduce any copyrighted material contained within this report. 


\section{Contents}

Abstract

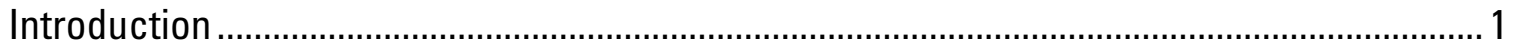

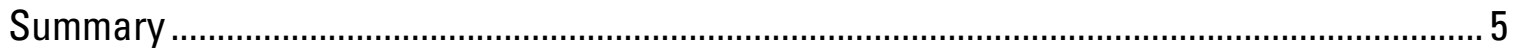

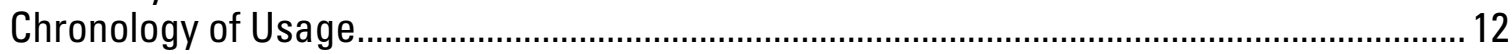

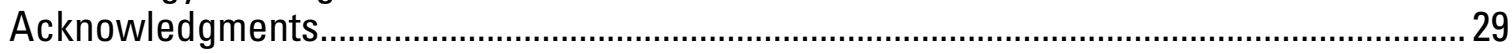

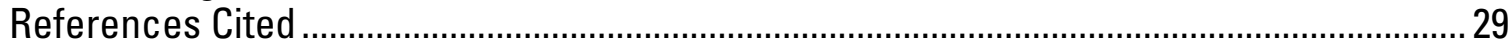

\section{Figures}

Figure 1. Index map of coastal southern California ....................................................

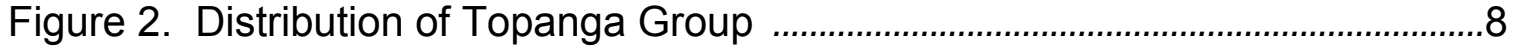

Figure 3. Chronological chart showing ages of Miocene rocks....................................... 11 


\title{
The Miocene Topanga Group of Southern California-A 100-Year History of Changes in Stratigraphic Nomenclature
}

\author{
By R.H. Campbell ${ }^{1}$, T.H. McCulloh ${ }^{2}$, and J.G. Vedder ${ }^{3}$
}

\section{Abstract}

A review of selected literature summarizes the origin and chronology of changes in usage of "Topanga" in the Miocene stratigraphic nomenclature of the Los Angeles Basin and adjacent areas in southern California. The review was done to summarize and reconcile some differences in Miocene stratigraphic nomenclature as applied to geologic map compilations of the Santa Ana (Morton, 2004), San Bernardino (Morton and Miller, 2003), Long Beach (Saucedo and others, 2003) and Los Angeles (Yerkes and Campbell, 2005) 30' x 60' quadrangles, all of which are products of the cooperative (California Geological Survey-U.S. Geological Survey) Southern California Areal Mapping Project (SCAMP). The deposition of the Topanga Group spans about 6 my (from as old as about $18 \mathrm{ma}$ to as young as about $12 \mathrm{ma}$ ), and the sequence of included strata records changes in provenance and depositional environments that are contemporaneous with part of a major Miocene tectonic episode in southern California -- the "basin-inception phase" in the evolution of the Neogene Los Angeles basin (Yerkes and others, 1965). The area of Topanga deposition extends to the southern, eastern, northern, and northwestern sides of the Los Angeles basin, as well as the southern part of the eastern Ventura Basin. Topanga beds are inferred to underlie the thick upper Miocene and Pliocene deposits of the central Los Angeles Basin and the southern part of the eastern Ventura Basin; however, they have been reached by drilling only in marginal areas, where the overlying deposits are relatively thin. Post-Topanga strata were deposited in more-restricted areas of rapid subsidence. Selected papers are summarized as they relate to the Topanga nomenclature, and are presented in chronological order.

\section{Introduction}

In the century since Arnold (1907) described a marine molluscan fauna from a locality near the head of Topanga Canyon, the name "Topanga" has become embedded in the geologic literature of southern California stratigraphy. That fossil locality was

\footnotetext{
${ }^{1}$ U.S. Geological Survey Scientist Emeritus, c/o Department of Earth Sciences, University of California, Riverside, Riverside, CA 92521

${ }^{2}$ U.S. Geological Survey Scientist Emeritus, 7136 Aberdeen Avenue, Dallas, TX 75230

${ }^{3}$ U.S. Geological Survey Scientist Emeritus, 285 Golden Oak Dr., Portola Valley, CA 94028
} 
included in a stratigraphic unit mapped by W.S.W. Kew (1924) along the north flank of the central Santa Monica Mountains as the Topanga Formation. (Kew had introduced the name in a short paper published in 1923; however, the map and unit descriptions in the 1924 paper provide a more complete definition.) Within a few years of its introduction by Kew (1923), "Topanga Formation" was the name applied to middle Miocene marine strata in a wide area of the Los Angeles Basin and its margins (e.g., English, 1926). In the 1940's and 1950's, geologic mapping in the Santa Monica Mountains by Cordell Durrell and students at the University of California, Los Angeles, led Durrell (1954) to recognize that the type Topanga Formation in the Santa Monica Mountains included three units of formation rank, which he termed the "Upper Topanga, Middle Topanga, and Lower Topanga Formations." Durrell's terminology did not meet requirements subsequently established by the American Commission on Stratigraphic Nomenclature (1961), so Yerkes and Campbell (1979) named the Topanga Group to include the three Topanga formations of Durrell (1954), and introduced the names "Topanga Canyon Formation" and "Calabasas Formation" for Durrell's "Lower Topanga Formation" and "Upper Topanga Formation", respectively, in the central and western Santa Monica Mountains. Because the Middle Topanga Formation of Durrell (1954) includes volcanic strata named "Conejo Volcanics" by Talliaferro (1924) in the western Santa Monica Mountains, Yerkes and Campbell (1979) followed the usage of Blackerby (1965) and extended the Conejo Volcanics to the central Santa Monica Mountains. Yerkes and Campbell (1979) did not attempt specific correlations of the Topanga Group formations in the central and western Santa Monica Mountains with subdivisions of "Topanga Formation" rocks as mapped by Hoots (1931) in the eastern Santa Monica Mountains, nor to rocks mapped by others as "Topanga Formation" in the central Los Angeles Basin and around its northern, eastern and southern margins.

The stratigraphic nomenclature currently used for Tertiary and Late Cretaceous rocks in and around the Los Angeles Basin has evolved from the work of many individual studies over the $20^{\text {th }}$ Century. Early workers tended to extend formation names such as Chico, Martinez, Domengine, Vaqueros, Temblor, and Monterey from type localities in central and northern California, to southern California rock units on the basis of similar faunal elements and similar lithologies. Some of these names also became identified with molluscan faunal "Stages" (e.g., Weaver and others, 1944). Although some southern California map units, notably the Vaqueros Formation and the Monterey Formation (or Monterey Shale), still retain those names, others have subsequently received local names which reflect differences in lithofacies and relationships to adjacent units, or to discontinuities at some high-angle faults. For example, the widely recognized Monterey Shale has been discriminated from partly or wholly coeval units in southern California, such as the Puente and Modelo Formations and the Topanga Group, on the basis of lithology, dominant source terrain, depositional environment, and biogenic content. Intertonguing marine and nonmarine strata, representing shifting shorelines, have been assigned to hybrid names (e.g., the "undifferentiated Sespe and Vaqueros Formations" in the northern Santa Ana Mountains mapped by Schoellhamer and others, 1981, and described, p. 31-37), or to discrete members, for example the Piuma Tongue of the Sespe Formation in the Santa Monica Mountains - a nonmarine sandstone-siltstone tongue described by Yerkes and Campbell $(1979$, p. 10-11) that separates two marine sandstone beds that carry mollusks assigned to the "Vaqueros Stage".

This paper reviews the historic usages of the terms "Topanga fauna", "Topanga Formation", and "Topanga Group", and attempts to reconcile an evolving terminology 
with ongoing map compilations; it is not intended as an extension or refinement of correlations. It was undertaken in order to summarize and reconcile some differences in Miocene stratigraphic nomenclature as applied to geologic map compilations of the Santa Ana (Morton, 2004), San Bernardino (Morton and Miller, 2003), Long Beach (Saucedo and others, 2003) and Los Angeles (Yerkes and Campbell, 2005) 30' x 60' quadrangles, all of which are products of the cooperative (California Geological Survey-U.S. Geological Survey) Southern California Areal Mapping Project (SCAMP). Figure 1 shows (dashed outline) the approximate area of those four 30' x 60'quadrangles and their relations to major physiographic features.

As geologic work progressed through a century, changes in stratigraphic nomenclature have been accompanied by refinements and revisions of paleontological interpretations of stratigraphic zonations, development of new paleontologic and isotope dating tools for determining unit ages, and refinements in regional and world-wide correlations leading to changes in the geologic time scale. The publication in 1961 of the "Code of Stratigraphic Nomenclature" (American Commission on Stratigraphic

Nomenclature, 1961), and subsequent revisions, offers a uniform set of guidelines for the nomenclature of lithostratigraphic, chronostratigraphic and geostratigraphic units. This paper does not attempt to fit the terminology of various authors, at various times, into the structure of current usage, and age-stratigraphic descriptors such as "Stage" and "zone" reflect the usages of published sources at the time of publication. For example, papers published over several decades in the middle $20^{\text {th }}$ Century commonly referred to "Vaqueros", "Temblor", "Relizian", and "Luisian", as "Stages", whereas current preferred usage emphasizes their geographically restricted usefulness for correlation, and would identify the "Vaqueros" and "Temblor" as "California Molluscan Stages" (CMS) (Bartow, 1992), and would identify the "Relizian" and "Luisian" as "Benthic Foraminiferal Stages" (BFS) (Barron and Isaacs, 2001). The transitions to this usage and the incorporation of nannofossil zonations and paleomagnetic reversal chronozones in the geologic time scale have not been abrupt and comprehensive, and we have not attempted to revise usages that appear in reports that predate current preferences. We have also avoided superimposing current chronostratigraphic usages on older correlations; and, within the scope of seeking uniformity in map unit labels for a large area, we have tried to retain the terminologies as they were applied by the various original authors. In addition, we have not attempted to update fossil nomenclature used by the cited authors to conform to current synonymy. 


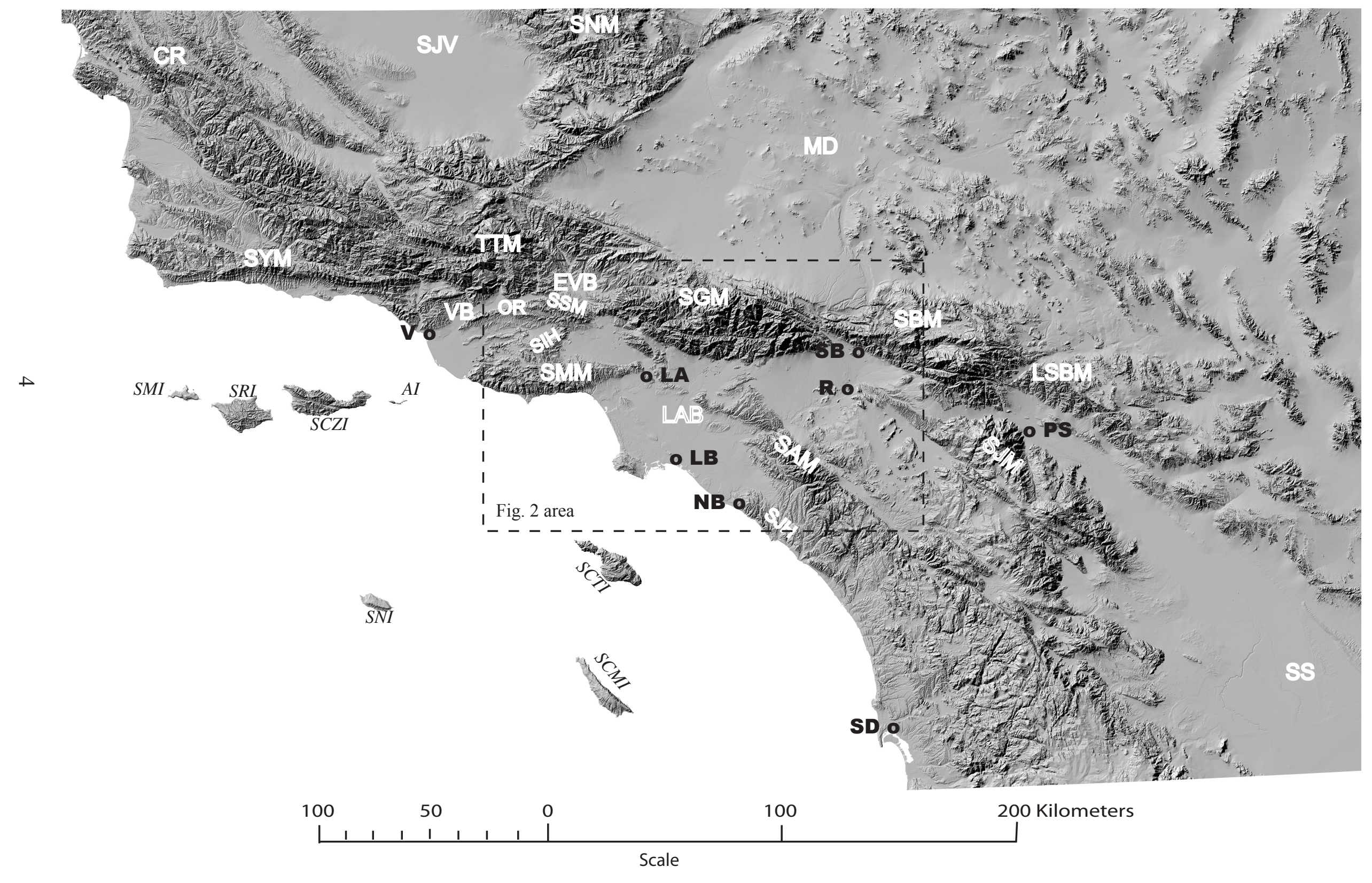

Figure 1. 
Figure 1 (preceding page). Index map of coastal southern California showing selected physiographic features and area of Figure 2. Shaded relief image prepared by R.M. Alvarez.

Islands (in italics): SMI, San Miguel Island; SRI, Santa Rosa Island; SCZI, Santa Cruz Island; Al, Anacapa Island; SNI, San Nicolas Island; SCTI, Santa Catalina Island; SCMI, San Clemente Island.

Physiographic features (in white): LAB, Los Angeles Basin; VB, Ventura Basin; EVB, eastern Ventura Basin; CR, California Coast Ranges; SJV, San Joaquin Valley; SNM, southern Sierra Nevada Mountains; MD, Mojave Desert; SS, Salton Sea; SYM, Santa Ynez Mountains; TTM, Topatopa Mountains; SGM, San Gabriel Mountains; SBM, San Bernardino Mountains; SMM, Santa Monica Mountains; SAM, Santa Ana Mountains; LSBM, Little San Bernardino Mountains; SJM, San Jacinto Mountains; OR, Oak Ridge; SSM Santa Susana Mountains; SIH, Simi Hills; SJH, San Joaquin Hills.

Cities (black): V, Ventura; LA, Los Angeles; SB, San Bernardino; R, Riverside; PS, Palm Springs; LB, Long Beach; NB, Newport Beach; SD, San Diego.

\section{Summary}

The Topanga Formation was first named and mapped by Kew (1923; 1924), who described it as a sedimentary and volcanic map unit, bounded by the overlying Modelo Formation and the underlying Sespe or Vaqueros Formations. The name was taken from the Topanga anticline area, near the head of Topanga Canyon, on the north flank of the Santa Monica Mountains. The map unit includes the fossil locality from which Arnold (1907) had reported a molluscan assemblage that became widely known as the "Topanga fauna". As mapped by Kew (1924), the Topanga Formation includes the Fernwood and Cold Creek Members of the Topanga Canyon Formation, the Conejo Volcanics, and the Calabasas Formation, all of which were assigned to the Topanga Group by Yerkes and Campbell (1979). Kew (1924) also comments that strata earlier mapped as part of the Vaqueros Formation in the Simi Valley area (Kew, 1919) ought to be considered as part of the Topanga Formation. On the south flank of the Santa Monica Mountains, beds of the Calabasas Formation, the Conejo Volcanics, and the Topanga Canyon Formation are juxtaposed against different lithofacies of the same ages by the Malibu Coast Fault.

Arnold (1907) described his fossil locality as "... at the head of Topanga Canyon, three miles south of Calabasas ...”, and a more precise geographic and stratigraphic position is not known to us. Since the middle of the $20^{\text {th }}$ Century, the best-known locality in that vicinity has been a road cut on Old Topanga Road, in a tributary to Dry Canyon, in the Malibu Beach 7.5' quadrangle, near its northern boundary with the Calabasas 7.5' quadrangle (see, especially, Susuki, 1951). As mapped by Kew (1924), that locality is stratigraphically near the middle of the Topanga Formation, but below the volcanic rocks and post-volcanic strata that he included in his Topanga Formation. Yerkes and Campbell (1980) place the locality within the middle part of the Cold Creek Member of the Topanga Canyon Formation. Kew (1924, p. 47-48) states, “... the Topanga formation is characterized by a fauna similar to that of the 'Temblor formation' of the San Joaquin Valley, whereas the Vaqueros contains a markedly different fauna at its type locality on Vaqueros Creek, Monterey County." This comment characterizes the 
Topanga Formation as a biostratigraphic unit (in addition to its description as an allostratigraphic unit) and in the context of the North American Stratigraphic Code (2005), it seems to be an "assemblage biozone". The dual characterization of the Topanga Formation, as both allostratigraphic and biostratigraphic, probably contributed to the subsequent use of the name in the Los Angeles Basin and vicinity.

Deposition of the Topanga Group spans the time interval identified by Yerkes and others (1965, p. A17 and figure 9, p. A31) as the "basin-inception phase" in the evolution of the Los Angeles Basin. The earliest deposits of the Topanga Group in the central Santa Monica Mountains and the Santa Ana Mountains appear to reflect a continuation of the shifting shoreline conditions evidenced in the underlying Vaqueros and Sespe Formations and their intertonguing relationships. Deposition continued during block faulting that initiated the formation of localized basins and uplifted areas, some of which exposed basement rocks to erosion. Eruptions from one or more volcanic centers locally and temporarily interrupted continuing sedimentation. Volcanism ceased before the uppermost Topanga Group beds were laid down unconformably over the volcanics and older rocks. Before the end of Topanga deposition, the outlines of the ancestral Los Angeles and eastern Ventura Basins can be recognized. The central parts of these basins subsequently subsided rapidly, and received thick late Miocene and Pliocene marine sedimentary deposits.

The stratigraphic changes recorded in Topanga Group deposition represent a disruption of earlier depositional conditions. Reconstructed Paleogene shorelines appear to mark a continuous west- or southwest-facing margin of the North American continent (e.g.: Yerkes and others, 1965; Yerkes and Campbell, 1971; Wright, 1991; McCulloh and others, 2000). The subsidence of the Los Angeles and Ventura basins (which received thick marine sedimentary deposits in the late Miocene and Pliocene), and the formation of discrete marine basins and ridges in the southern California borderland, appear to have begun in the Miocene (e.g.: Yerkes and others, 1965; Wright, 1991, fig. 36). The structural rearrangement is probably associated with breakup of the oceanic Farallon plate and the attachment of parts of the Pacific margin of the North American continental plate to the Pacific oceanic plate, as described by Atwater (1970), and updated by Atwater and Stock (1998). Topanga deposits record some effects of this structural upheaval by local differences in depositional environments that reflect the initial stages of subsidence of the Los Angeles and Ventura Basins, and by changes in source terrains as represented by changes in detrital characteristics of Topanga-age deposits. For example, chips of slate basement rocks, volcanic detritus, and fossil-bearing clasts of Paleocene, Eocene and Miocene strata are found locally within the Calabasas Formation of the central Santa Monica Mountains.

Topanga-age deposits in the San Joaquin Hills contain the earliest appearance of Catalina Schist detritus in the Tertiary sedimentary record of that area. In the San Joaquin Hills the San Onofre Breccia (Relizian and older Luisian benthic foraminiferal stages -- BFS), a unit containing large angular blocks of Catalina Schist, overlies strata that Vedder (1975) assigned to the "Topanga Formation." Vedder (1975) recognized three members of his "Topanga Formation", the Paularino, Los Trancos and Bommer, youngest to oldest, respectively. Morton and Miller (2006) elevated the members to formation status as parts of the Topanga Group. The upper two (the Paularino and Los Trancos Formations) contain interbeds with varying amounts of Catalina Schist detritus (Vedder, 1975); but Catalina Schist detritus is not reported from the lowest unit, the Bommer Formation. In the San Joaquin Hills area, east of the Newport-Inglewood Fault Zone (fig. 2), Topanga-age beds overlie strata of the Vaqueros and Sespe Formations and 
are overlain by San Onofre Breccia, in turn, succeeded by Monterey Shale which also contains lenses with blueschist detritus. In the subsurface west of the NewportInglewood Fault Zone, some strata containing Catalina Schist detritus have been assigned to the Topanga Formation by some workers. However, on the Palos Verdes Peninsula, also west of the Newport-Inglewood Fault Zone, beds containing Catalina Schist detritus occur as interbeds in the Monterey Shale (middle and upper Miocene), which is underlain there by a Catalina Schist basement without intervening Paleogene strata (Woodring and others, 1946). Further northwest, Catalina Schist detritus is common south of the Malibu Coast Fault in sandstone and conglomerate interbeds in strata ranging from Saucesian BFS to upper Mohnian BFS - early Miocene to late Miocene in age. The oldest of these beds overlie inferred Catalina Schist basement. In the far western Santa Monica Mountains (fig. 1) detrital glaucophane is present in some Vaqueros (?) Formation sandstone (Oligocene-lower Miocene) north of the Malibu Coast Fault. Vedder and Howell (1976) reviewed the distribution of Miocene detritus from the Catalina Schist in the California Continental Borderland islands, coastal areas, and available subsea data, and examined implications for the sources of the detritus.

The section to the south of the Malibu Coast Fault in the central and western Santa Monica Mountains consists of Catalina Schist basement overlain directly by Miocene basaltic volcanic rocks (chiefly submarine), the Zuma Volcanics of Yerkes and Campbell (1979). The volcanics are succeeded by marine mudstone, sandstone, and conglomerate of the Trancas Formation, which is succeeded by calcareous and dolomitic shales of the Monterey Shale. Catalina schist detritus occurs in sandstone and conglomerate interbeds in both the Monterey Shale ('Relizian or Luisian' and Mohnian BFS's in this area) and the Trancas Formation (Saucesian and 'Relizian or Luisian'). In general, this section resembles the section in the Palos Verdes Peninsula, and lacks the Cretaceous and Paleogene strata recognized in the Santa Monica Mountains to the north of the Malibu Coast Fault. The San Joaquin Hills is the northernmost area where Catalina Schist detritus is recognized in beds of middle Miocene age that are assigned to the Topanga Group and that clearly overlie Paleogene strata associated with an eastern basement source terrain. Blake's (1991, Fig. 2.) columnar section for the San Joaquin Hills suggests that the lower part of the Bommer Formation is older (possibly as old as Saucesian BFS) than the base of the Topanga Group (Relizian BFS) in the Santa Monica and Santa Ana Mountains sections. To the north of the San Joaquin Hills, the San Onofre Breccia (in the restricted usage of Yeats, 1973, p. 123) occurs in the subsurface only as far north as the Huntington Beach oil field (Yeats, 1973, Fig. 1). Further north, beds in the subsurface that contain Catalina Schist detritus are referred to as "schistconglomerate" (as contrasted with poorly-sorted sedimentary breccia containing abundant large clasts of Catalina Schist). Schist-conglomerate beds are interbedded with sandstone derived from eastern sources (Yeats, 1973, p. 123), and lie below siltstone from which Luisian microfossils were reported by Wissler (1943). Because most subsurface correlations with the "Topanga Formation" have been based on the presence of Relizian or lower Luisian foraminifers, it seems likely that any equivalents of a Saucesian BFS Bommer Formation would not have been included in subsurface strata assigned to the "Topanga Formation." Figure 2 shows the distribution of outcrops that have been assigned to the "Topanga Formation" (Group) and of coeval strata commonly assigned to the middle Miocene part of the Monterey Shale. 


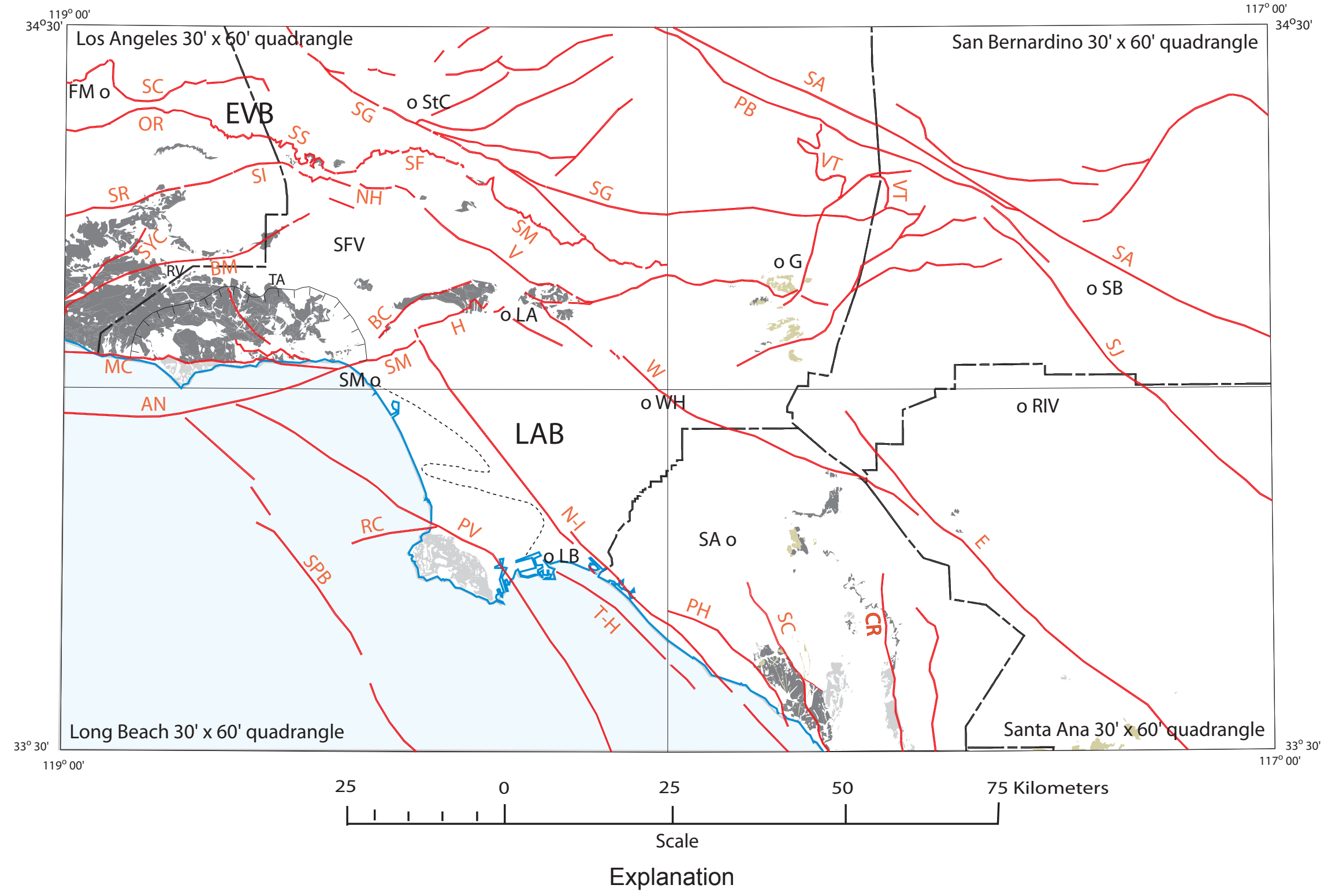

Beds commonly assigned to the Topanga Group

Beds coeval with and tentatively assigned to the Topanga Group by some authors

Beds partly coeval with Topanga Group but commonly assigned to Monterey Formation and associated facies

Figure 2. 
Figure 2 (preceding page). Distribution of Topanga Group outcrops and of coeval beds in the vicinity of the Los Angeles and eastern Ventura Basins. Map shows selected features, city centers, and faults.

Physiographic and geologic features: EVB, eastern Ventura Basin; LAB, Los Angeles Basin; SFV, San Fernando Valley; TA, Topanga Anticline area; RV, Russell Valley area.

Cities: FM, Fillmore; StC, Santa Clarita; SB, San Bernardino; LA, Los Angeles; SM, Santa Monica; WH, Whittier; RIV, Riverside; SA, Santa Ana; LB, Long Beach; G, Glendora.

Faults - SC, San Cayetano; OR, Oak Ridge; SS, Santa Susana; SF, San Fernando; SM, Sierra Madre; SG, San Gabriel; PB, Punchbowl; SA, San Andreas; VT, Vincent Thrust; SR, Santa Rosa; SI, Simi; SYC, Sycamore Canyon; BM, Boney Mountain; AN, Anacapa; SM, Santa Monica; BC, Benedict Canyon; H, Hollywood; W, Whittier; SJ, San Jacinto; E, Elsinore; SC, Shady Canyon; $\mathrm{PH}$, Pelican Hills; N-I, Newport-Inglewood; T-H, Thums-Huntington Beach; PV, Palos Verdes; RC, Redondo Canyon; SPB, San Pedro Basin.

Hachured line north of the Malibu Coast Fault is the approximate limit of an area where outliers and windows in Cretaceous through middle Miocene strata indicate complex low-angle faulting in late-middle Miocene, possibly extending into early-late Miocene.

Dashed line between the Newport-Inglewood zone of faulting and folding and the Palos Verdes fault (from Wright, 1991, Figure 5) indicates subsurface boundary separating eastern facies assigned to the Topanga Group from western facies including "schist conglomerate" (beds containing conglomerate clasts consisting of greenschist or blueschist, or both, metamorphic facies, but which are not assigned to the San Onofre Breccia).

Compiled from digital source maps (Los Angeles, San Bernardino, Santa Ana, and Long Beach 1:100,000-scale geologic maps), with supplemental data from Wright (1991).

While the Topanga nomenclature was being extended to correlative units, the tools for geologic correlation were also evolving. The last half of the $20^{\text {th }}$ century saw significant refinements and revisions of the geologic time scale for the Miocene Epoch. New correlation tools, including zonation by diatoms and calcareous nannofossils, and a paleomagnetic time scale, were combined with isotope age data to provide an improved correlation of provincial and world-wide geologic ages. Figure 3 (after McCulloh and others, 2002, Figure 4) illustrates these correlations for the southern California Miocene. As a result of these revisions, "Topanga Formation" strata assigned to a "middle Miocene age" in some earlier studies are now recognized as of early and middle Miocene age; the underlying Vaqueros Formation strata are now recognized as ranging from Oligocene to early Miocene in age; and the overlying Modelo Formation is recognized as of middle and late Miocene age. The isotope ages of Miocene volcanic rocks, as summarized by McCulloh and others (2002), indicate that many of volcanics found around the margins of the Los Angeles Basin fall within the age range of the Conejo 
Volcanics, and are mostly within the middle Miocene. However, some volcanics from the southern California Borderland may be of early Miocene age. The age-range embraced by the entire Topanga Group (late Saucesian to early Mohnian BFS), as shown on Figure 3, is correlative with paleomagnetic chrons C5D through C5A, and is about 18 ma to about 12 ma. The tectonism that accompanied Topanga deposition is associated in time with the capture of the Monterey microplate by the Pacific plate, which Atwater and Stock (1998, p. 392) place at about 18 ma.

The Monterey microplate is a fragment of the Farallon Plate that became attached on the east to the Pacific Plate, at which time it ceased subducting eastward beneath the North American Plate (Atwater and Stock (1998). This probably marks the earliest time that part or all of the Salinian Block (a fragment of the North American Plate) could begin to move with the Pacific Plate. The Salinian block is now bounded on the east by the San Andreas Fault and on the west by the continental slope, where it is attached to Pacific Plate oceanic crust. The southern boundary lies within the western Transverse Ranges. Further south, the Farallon Plate continued subduction eastward. The area south of and adjacent to the Salinian Block was subjected to extensional deformation in middle Miocene to earliest Pliocene time, followed by compressional deformation in later Pliocene, Pleistocene, and Holocene time (Campbell and Yerkes, 1976, p. 552 and fig. 5). With the possible exception of some northward overlap in the northern part of the eastern Ventura Basin, Topanga Group deposition was entirely south of the southern margin of the Salinian Block, during the early stages of extensional deformation.

Even though contiguous deposition and common provenance were not everywhere demonstrated, the name Topanga Formation has been extended, chiefly by biostratigraphic correlation, from the allostratigraphic unit initially mapped and described by Kew. It has been applied to age-correlative units based on molluscan fossils for littoral and shelf depositional environments (e.g., Durham, 1954), and also on foramiferal fossils in shelf, slope, and bathyal depositional environments (e.g., Kleinpell, 1938; Wissler, 1943). In the subsurface of the Los Angeles basin, strata correlated with the "Topanga Formation" on the basis of Relizian BFS and lower Luisian BFS Foraminifera have been assigned to the Topanga Group or the "Topanga Formation". In regional summary publications, some authors have used "Topanga Group" (e.g., Blake, 1991; Wright, 1991), but have not been comprehensive in reassigning previously designated members to formation status. Other workers, however, have continued to use the term "Topanga Formation" (e.g., Schoellhamer and others, 1981; Morton, 2004). In addressing a need for uniformity in stratigraphic nomenclature for the purpose of edgematching geologic map compilations for the Southern California Areal Mapping Project (SCAMP) we chose to use the term "Topanga Group" for the middle Miocene shelf, paralic, volcanic, and bathyal fan strata; however, we recognize that some older formations within the group may have begun to deposit as early as the Saucesian BFS, and some younger units may not have ceased their deposition until early Mohnian BFS (fig. 3). 


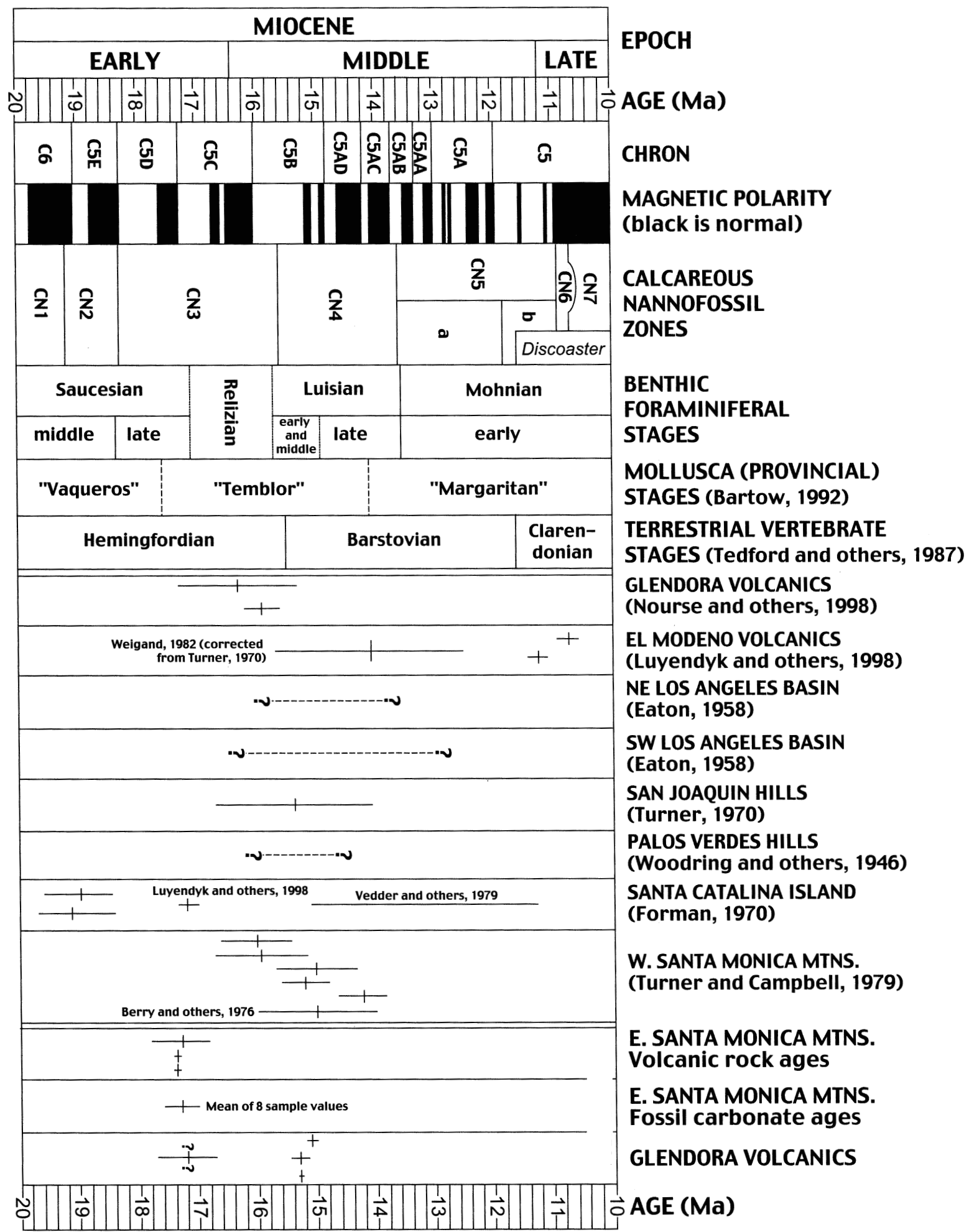

Figure 3. Chronological chart showing published ages of Miocene volcanic rocks in and around the Los Angeles basin, from McCulloh and others (2002). References to pre-2002 publications are shown beside rows; ages in the last three rows are from the study by McCulloh and others (2002). 
Figure 3 (preceding page). Chronological chart showing ages of Miocene rocks in and around the Los Angeles Basin, from McCulloh and others, (2002, fig. 4, p. 10).

The chart compares isotope ages of Miocene volcanic rocks and shows their correlation with Miocene subdivisions, paleomagnetic chrons, magnetic polarity, calcareous nannofossil (nannoplankton) zones, benthic foraminiferal stages, California molluscan stages, and terrestrial vertebrate stages. Solid lines represent volcanic ages with uncertainties and dashed lines represent less-certain age ranges. (The chronostratigraphic and biostratigraphic data were adapted from the compilation by Barron and Isaacs, 2001.)

\section{Chronology of Usage}

The following chronologic list of publications outlines a history of the usage of "Topanga Formation" and "Topanga Group" as applied in and around the margins of the Los Angeles Basin. The chronological list includes references to some relevant paleomagnetic and isotope age information, as well as to some revisions of the age ranges of Miocene biostratigraphic units.

1907 - Arnold (1907) described fossil mollusks from "lower Miocene" at the head of Topanga Canyon, 3 miles south of Calabasas, Los Angeles County, California. (At this time, the recognized Miocene subdivisions were "lower" and "upper"; "middle" was a later revision.) New species at this locality were shown to be accompanied by previously known species including Turritella ocoyana Conrad. This locality is one where many mollusk species are preserved in abundance in a relatively thin stratigraphic interval. (Although the range of Turritella ocoyana extends to subjacent and superjacent strata, it is abundant at the locality and in contiguous strata in many parts of the Santa Monica Mountains.) Since the early 1950's, the best known fossil locality is not within the Topanga Canyon drainage area, but is a road cut on Old Topanga Canyon Road, just northwest of the divide between Old Topanga Canyon and a tributary to Dry Canyon. Old Topanga Canyon is an east-southeast flowing tributary to Topanga Canyon, and the present route of Topanga Canyon Road follows a south-flowing tributary further to the east.)

1923 - In a short paper summarizing stratigraphic observations in a large part of southern California, Kew (1923) named the Topanga Formation as a middle Miocene marine series, and restricted the name, Vaqueros Formation, to lower Miocene series. The paper proposed revisions of some terminology used by Eldridge and Arnold (1907), and extends the name, Topanga Formation, to similar stratigraphic units exposed in the Puente Hills, Santa Ana Mountains, and San Joaquin Hills, also providing a brief description of each section. Kew's (1923) nomenclature of Miocene formations as Vaqueros (lower Miocene), Topanga (middle Miocene), Mint Canyon (upper Miocene), and Modelo (upper Miocene) was subsequently used by many workers in southern California.

1924 - Kew (1924) published the first map showing a stratigraphic unit named the Topanga Formation. The map shows the Topanga Formation in the Topanga Anticline area underlying an unconformity at the base of the Modelo Formation, with its base on the Sespe Formation. As mapped, the formation includes a thin interbed of basaltic volcanic rocks. The map also shows the base of the formation further west, in the Russell Valley-Conejo Valley area, as a volcaniclastic 
conglomerate underlain by volcanics, which he describes as "...the lower Miocene igneous series."

The southern boundary of Kew's map area is north of most of the western Santa Monica Mountains. He mapped the base of the Modelo Formation only in the area of the Topanga Anticline (on the east) and the Russell Valley area (on the west), and did not delineate the rocks that lie below the Modelo between these areas. As a result, Kew did not recognize that the volcanics he mapped in the Russell Valley area were stratigraphically equivalent to the thin volcanic member he mapped as within the Topanga Formation (middle Miocene) in the Topanga Anticline area, instead referring to the volcanic rocks of the Russell Valley area as a “... lower Miocene igneous series.” Subsequent mapping (Durrell, 1954) showed that the thin volcanic member mapped by Kew in the Topanga Anticline area becomes very much thicker progressively westward (the Middle Topanga Formation of Durrell, 1954; the Conejo Volcanics of Yerkes and Campbell, 1979), that the post-volcanic Topanga (Upper Topanga Formation of Durrell, 1954; Calabasas Formation of Yerkes and Campbell, 1979) becomes very thin in the Russell Valley area, and that the base of the Modelo Formation becomes progressively more conformable westward over the underlying Topanga.

Kew also comments (1924, p. 47-48) about earlier work: "In the report on Simi Valley (Kew, 1919) the series of strata here named Topanga formation were included in part in the Vaqueros formation and in part in the Modelo formation. Later work has shown that these rocks, which are well exposed along the Topanga anticline, should be separated as a distinct formation. Wherever recognized they are unconformably overlain by the Modelo formation as here restricted." His observations from the Simi Valley area probably led him to include the Vaqueros Formation (as well as the Sespe Formation) as a lower limiting horizon for the Topanga. Kew (1924) also recognized that many molluscan fossils were similar to those in the Temblor Formation of the central California Coast Ranges, and restricted the usage of Vaqueros Formation to underlying beds.

1926 - English (1926) mapped and described the Topanga Formation in the Puente Hills and Santa Ana Mountains north of latitude $33^{\circ} 45^{\prime}$. He assigned a middle Miocene age to the formation and stated that it "... belongs to the Turritella ocoyana faunal zone."

1931 -- Hoots (1931) mapped the Santa Monica Mountains east of Topanga Canyon Road; the map does not extend westward to the area where Kew (1924) described the type section containing Arnold's (1907) “Topanga fauna". Note that the "Topanga Canyon Road" that marks the western boundary of Hoots' map is not the "Old Topanga Road" where Arnold (1907) reported the "Topanga fauna" locality. Hoots (1931) used the name "Topanga Formation" to include prevolcanic, volcanic, and post-volcanic "middle Miocene" rocks. He recognized that both intrusive and extrusive volcanics are present, but included both in the same map unit with the same label. Hoots' map locations and fossil lists indicate that nearly all of the molluscan collections assigned to the "Temblor Stage" are from beds intruded by, interbedded with, or stratigraphically below volcanics. In the post-volcanic strata assigned to the Topanga Formation, mollusk species are rare, and only one collection contained an assemblage indicating a "Temblor Stage".

1932 - Gale's (1932) introductory chapter to a guidebook that contains contributions from many authors includes a correlation chart by W. P. Woodring that applies 
the name "Topanga formation" to strata in the San Pedro Hills (Palos Verdes Peninsula). The chapter by H. W. Hoots, "General Geology of the Los Angeles Basin", includes a stratigraphic chart that describes the "known distribution" of the "Topanga formation" as including the San Joaquin Hills, Santa Ana Mountains, Puente Hills, Repetto Hills, San Pedro Hills, Santa Monica Mountains, and beneath the Los Angeles Basin. The chapter by W.S.W. Kew (1932) describes an excursion route from Los Angeles to Santa Barbara, and includes a map showing the distribution of the "Topanga formation" north of the $34^{\text {th }}$ parallel.

1932 - Loel and Corey's (1932) classic volume on the Vaqueros Formation includes a check list (p. 168-174) of the "Fauna of the Temblor Horizon ..." indicating extensive collections from the Santa Monica Mountains from beds called Topanga Formation by Kew (1924). Their discussion of the relationship of the "Vaqueros fauna" to the "Temblor fauna" (p. 139-156) recognizes an overlapping of ranges they identified as a "Vaqueros-Temblor transition faunule and zone"; however, they assert (p. 139) that "...The Temblor fauna assemblage invariably occurs stratigraphically above that of the Vaqueros, although in some sections there is a minor intermediate association of a few forms otherwise confined to one or the other formation...." Their chapter, "Historical Review of the Paleontology of the Vaqueros Formation", (Loel and Corey, 1932, p. 46-50) provides an excellent summary of literature on the California lower and middle Miocene Paleontology and stratigraphic nomenclature from 1849 through 1930, and discusses conflicting conclusions of different authors about distinguishing between the Vaqueros and Temblor as stratigraphic units on the basis of their macrofossil contents. Their correlation chart (Loel and Corey, 1932) suggests that the pre-volcanic beds that Kew (1924) included in his Topanga Formation fall in the "Vaqueros-Temblor transitional zone", astride the boundary between lower Miocene and middle Miocene series. The chart also refers the age of the "Temblor fauna" to middle Miocene, whereas many earlier workers considered it an "upper part" of the lower Miocene at a time when the California Miocene series was subdivided into only upper and lower parts.

1938 - Kleinpell (1938, p. 92) coined new names for six "California Miocene Stages" and subdivided each "Stage" into "Zones" based on benthic foraminiferal assemblages. Kleinpell's correlation chart (his figure 14) equates the base of the Zemorrian Stage with the base of the lower Miocene Series, equates the Saucesian-Relizian Stage boundary with the approximate base of the middle Miocene Series, and equates the Luisian-Mohnian Stage boundary with the approximate base of the upper Miocene Series. Kleinpell's biozone of Turritella inezana extends from the base of the Zemorrian Stage to the middle of the Luisian Stage, and the biozone of Turritella ocoyana extends from the base of the Saucesian Stage to the Luisian-Mohnian Stage boundary.)

Kleinpell (1938) chose not to include the Topanga Formation of the Santa Monica Mountains in his correlation chart (his figure 14), citing “...the vagueness of its' stratigraphic limits...", instead showing overlapping Vaqueros and Temblor Formations. This is difficult to reconcile with an upper limit marked by the unconformity at the base of the Modelo Formation and a lower limit imposed by nonmarine redbed sandstone of the Sespe Formation; however, it may relate to some lithologic similarities between the Modelo Formation and the upper part of the Topanga Formation as mapped by Hoots (1931). 
1938 - Soper (1938) extended mapping about 5 miles westward from the western edge of Hoots' (1931) map to Malibu and Las Virgenes Canyons, filling the gap between the maps of Kew (1924) and Hoots (1931) and mapping the Topanga Anticline area in more detail. His map and text recognize the three-fold subdivision of the Topanga Formation, into lower and upper members of marine sandstone, siltstone and shale, separated by a middle member of volcanic rocks. His map includes the name locality for the Topanga Formation. His base maps (and, presumably, his compilation sheets) were the Dry Canyon (northern) and Las Flores (southern) 6minute USGS topographic quadrangles at a scale of 1:24,000.

1943 -Wissler (1943, p. 209-234), in the multiple-authored California Division of Mines Bulletin 118, "Geologic formations and economic development of the oil and gas fields of California", described the stratigraphic formations of producing zones in Los Angeles Basin oil fields and their correlations using foraminifers from wells and some surface outcrops in peripheral mountains and foothills. He correlated foraminiferal-based zones recognized in subsurface sections with Hoots' section of the Modelo Formation on Topanga Canyon Boulevard. He did not consider the pre-Modelo Topanga Formation of Hoots to contain Luisian foraminifers. Strata in oil fields of the west-side of the Los Angeles Basin that contain Luisian foraminifers were correlated with the Monterey Formation as exposed in the Palos Verdes Hills (including beds containing Catalina Schist detritus). He found strata containing Luisian foraminifera probably absent from east-side fields; and identified the Topanga Formation as containing Relizian and upper Saucesian foraminiferal assemblages.

Wissler's views apparently represented those of many micropaleontologists engaged in zoning Miocene subsurface strata in producing oil fields. Foraminifera recovered from drill cores and cuttings were the basis for detailed correlations of producing zones, most of which were in Pliocene or "upper Miocene" strata, and only a few in "middle Miocene" strata. In that scheme, most of the subsurface "Topanga" reported in the Los Angeles Basin, from east of the Newport-Inglewood zone and north of the San Joaquin Hills, probably excludes correlatives of the Calabasas Formation.

In the same volume (Jenkins, 1943), reports on the oil fields of the Ventura Basin do not use the term, Topanga Formation. Instead, formation names used for middle Miocene marine strata are Rincon Formation or Temblor Formation.

1944 -- The correlation chart (widely referenced) and discussions by the Western Cenozoic Subcommittee (Weaver and others, 1944) does not include the name Topanga nor describe its' stratigraphic position. Key molluscan elements are named as evidence of inclusion in the "Temblor Stage".

1951 - In a definitive paleontological study of the type area of the Topanga Formation, Susuki (1951) listed 103 species from a section about 8,150 feet thick and figured 39 of them. He identified a lower fossiliferous zone, succeeded by a thick unfossiliferous zone, a second fossiliferous zone, extrusive basalt, and a third and fourth fossiliferous zones separated by alternating sandstone and shale. The nomenclature proposed by Yerkes and Campbell (1979) placed Susuki's lower two fossiliferous zones in the Saddle Peak Member and Cold Canyon Member, respectively, of the Topanga Canyon Formation, separated by the nonmarine and paralic Fernwood Member of the Topanga Canyon Formation. The extrusive basalt is contiguous with the thick section of Conejo Volcanics further to the west, 
and the upper two fossiliferous horizons of Susuki (1951) lie within the Calabasas Formation of Yerkes and Campbell (1979). Although Susuki's results were not published, his documentation of the fossil elements in the type Topanga Formation influenced many workers in their assignment of strata containing those species assemblies to the Topanga Formation in southern California.

1954 - California Division of Mines Bulletin 170, R.H. Jahns, ed., contains several map sheets, charts, and reports that use "Topanga Formation"

The map and text discussion by Woodford and others (Chapter II, p. 71 and Plate 1) referred middle Miocene strata in and around the margins of the Los Angeles Basin to the "Topanga Formation", the "Monterey shale", or the "San Onofre Breccia." Differences in provenance of sandstone interbeds in deep water shales distinguished the upper Miocene Puente and Modelo Formations from the coeval parts of the Monterey shale. They report a mollusk (Aequipecten andersoni) from the "Buzzard Peak conglomerate member of the Topanga Formation" in the San Jose Hills, in the northeastern part of the Los Angeles Basin; except for that locality, their correlation appears to be based on middle Miocene foraminifera from interbedded (intertonguing) deep-water, fine-grained facies (especially in subsurface strata).

Durrell's map (Map Sheet 8) summarizes Santa Monica Mountains' stratigraphy and recognizes that three divisions of middle Miocene strata are extensive enough to be of formation rank. He named these units the "Upper, Middle and Lower Topanga Formations" respectively. His map shows continuous contacts for base and top of each formation, which demonstrate that the base of the Topanga Formation as mapped by Kew in the west (Russell Valley-Conejo Valley area) is stratigraphically equivalent to the contact at the top of Kew's "volcanic member" at the Topanga Anticline. The map also shows the unconformity at the base of the Modelo Formation extending west of Hoots' (1931) map from Topanga Canyon Road (the western edge of Hoots' map) as far as Las Virgenes Canyon, including the area north of the type "Topanga

Formation". The informal nomenclature proposed by Durrell (1954) was used by subsequent mappers until the 1961 publication of the North American Stratigraphic Code (more recently updated; The North American Commission on Stratigraphic Nomenclature, 2005) made some revisions advisable.

Durham's stratigraphic chart (Chapter 3, p. 24), which is keyed to the time scale used by Weaver and others' (1944), includes the "Topanga Formation" in both eastern and western parts of the Los Angeles Basin. The chart does not subdivide the Miocene, but shows "Vaqueros Stage" entirely in the lower part of the Miocene, succeeded by the "Temblor Stage".

Oakeshott and others' correlation chart (Chapter 3, Plate 1) of sedimentary formations in southern California recognizes "Topanga fm." in coastal San Diego and Orange Counties, Santa Ana Mountains and Puente Hills, Santa Monica Mountains, and eastern Ventura Basin (Simi Valley area). The chart places the Vaqueros Formation in the early Miocene and the Topanga Formation in the middle Miocene, as in earlier usage.

1954 - The geologic map of the northern Santa Ana Mountains by Schoellhamer and others (1954) shows substantial revisions of English's (1926) mapping of the Topanga Formation, and extends his mapping of the formation southeastward nearly six miles. 
In 1954 "Topanga Formation" was widely accepted usage for shallow marine rocks containing the "Turritella ocoyana fauna" (Temblor CMS fossil assemblage) around the margins of the Los Angeles Basin. In parts of the basin where strata represent a deeper-water environment, finer-grained strata containing foraminifers referred to the middle Miocene were also assigned to the "Topanga Formation", particularly where they show evidence of source areas to the north and east. In the western part of the Los Angeles Basin, deep marine strata of the same age were referred to the Monterey Formation. (The Monterey may include, in part, distal equivalents from the some of the same terrigenous sources as the Topanga, but is notable for interbeds containing clastic detritus from a "western" sediment sources (i.e., Catalina Schist detritus) and a greatly increased relative volume of marine organic material, which predominates in some sections. Sandstone intervals in the Monterey Formation also generally include a higher proportion of quartz relative to more-easily altered minerals and rock-fragments.) This usage of the name, Topanga Formation, was embedded in reports by the U.S. Geological Survey, the California Division of Mines, academia (as represented by faculty from UCLA, UCB, Pomona College, Caltech, etc.), and by most petroleum exploration and production geologists and paleontologists.

1955 - Shelton's map and discussion of the Glendora volcanic rocks (Glendora-AzusaPomona-San Jose Hills area) assigned strata overlying the volcanics to "...the middle Miocene Topanga formation...", and notes that although coarse-grained sandstones predominate, some with boulders of San Gabriel Mountains basement rocks, the fossil control reported is entirely from foraminifers in fine-grained interbeds. Interbeds included in the Glendora Volcanics yielded collections of foraminifers and fish scales of which "... all indicate Luisian (upper middle Miocene) age" (Shelton, 1955, p. 79). The overlying "Topanga Formation” was assigned to uppermost Luisian or possible lowest Mohnian Stages of Kleinpell (1938).

1957 - Vedder and others (1957) described three members of the Topanga Formation in the San Joaquin Hills. The map explanation shows an upper member, the Paularino Member, as lower Luisian or Relizian Stage, and includes andesite flow breccia and pods of sedimentary breccia in which the predominant clasts are andesite. The Paularino Member overlies the Los Trancos Member, which contains sparse Relizian foraminifers and consists of dark gray siltstone with interbeds of light gray medium-grained sandstone that is locally tuffaceous and contains clasts of glaucophane schist. The Los Trancos Member overlies the Bommer Member, which contains Turritella ocoyana and other early to middleMiocene mollusks. The Bommer Member is composed chiefly of coarse-grained sandstone, containing thin lenticular pebble conglomerate, interbedded in the middle and upper parts of the unit and thin beds of fine- to medium-grained sandstone. Catalina Schist detritus is present in the Paularino and Los Trancos Members, but not in the Bommer Member (Vedder, 1957; Vedder, 1975).

Unlike the section on the Palos Verdes Hills, where detrital glaucophane schist is found in beds overlying Catalina Schist basement, the parts of the section in the San Joaquin Hills that carry schist detritus overlie the Bommer Member of Vedder (1957), which, in turn, overlies older Tertiary and Upper Cretaceous strata.

1960 -- Sullwold (1960) recognized bathyal fan depositional characteristics in the Modelo Formation (Tarzana Fan). Apparently he did not recognize that the 
"Upper Topanga Formation" of Durrell (1954; Calabasas Formation of Yerkes and Campbell, 1979) is also dominated by submarine fan deposits in parts of the Santa Monica Mountains, and some strata from the "Topanga Formation" may have been included in his description of the Tarzana Fan.

1961 -- American Commission on Stratigraphic Nomenclature releases first version of the "Code of Stratigraphic Nomenclature" published in the American Association of Petroleum Geologists Bulletin, v. 45, no. 5, p. 645-665. Constraints imposed by the code, and subsequent changes and additions, flag a need for substantial revision of informal and formal stratigraphic nomenclature regarding the Topanga Formation of Kew (1924) and the Upper, Middle, and Lower Topanga Formations of Durrell (1954).

1961-1973 - A series of preliminary geologic maps (scale 1:12,000) of parts of the Malibu Beach, Topanga, and Point Dume 7.5' quadrangles were open-filed by the U.S. Geological Survey as progress reports on mapping in the Santa Monica Mountains, under a cooperative program with the Los Angeles County Engineer Department. These maps used Durrell's informal stratigraphic nomenclature, "Upper, Middle, and Lower Topanga Formations." Mollusk and foraminifer fossils collected from these strata were reported as "middle Miocene" (see, for example, Schoellhamer and Yerkes, 1961; Schoellhamer and others, 1962; Yerkes and others, 1964; Campbell and others, 1970; Yerkes and others, 1973. Their earlier experience mapping in the Santa Ana Mountains quickly led R. F. Yerkes and J. E. Schoellhamer to recognize many close similarities in the stratigraphic sections of the Santa Ana and Santa Monica Mountains).

1964 -- Durham and Yerkes (1964) list fossil mollusks from the Topanga Formation in the Puente Hills, whereas the earlier work (English, 1926) had found none.

1965 -- Yerkes and others (1965), in summarizing the geology of the Los Angeles Basin, generally avoided using formation names in their text, instead referring to a timestratigraphic nomenclature; however, their correlation chart (Plate 1) lists the Topanga Formation, and shows its age as spanning the Relizian and Luisian Stages of Kleinpell, 1938), which they equate with a middle Miocene age. Their assignment correlates Topanga deposition with a "basin-inception phase" in the evolution of the Los Angeles Basin, during which a persistent Late Cretaceous through early Miocene "prebasin phase of deposition" was disrupted by an episode of emergence and erosion that probably varied in degree and duration from one part of the area to another (Yerkes and others, 1965, p. A16-A19). In that framework, deposition of middle Miocene strata represents the transition from a relatively quiet tectonic state, dominated by broad regional features, to a different tectonic regime including accelerated subsidence and deposition in restricted areas during late Miocene through early Pleistocene time. (At the time this report was published, the "Vaqueros" CMS was still considered early Miocene and the Topanga molluscan fauna was considered middle Miocene.)

1965 - Campbell and others (1965) used Durrell's informal stratigraphic nomenclature in developing structural interpretations of rock distributions in the central Santa Monica Mountains.

1970 - The preliminary geologic map (scale 1:12,000) of the Point Dume quadrangle by Campbell and others (1970) used the informal nomenclature "Upper, Middle, and Lower Topanga Formations of Durrell (1954)" for middle Miocene strata north of the Malibu Coast Fault. South of the Malibu Coast Fault they used informal nomenclature: "unit b" for mudstones and interbedded sandstone and 
conglomerate (Trancas Formation of Yerkes and Campbell, 1979) and "unit bv" for volcanics (Zuma Volcanics of Yerkes and Campbell, 1979) underlying and intertonguing with the mudstone unit. Cretaceous, Paleogene, and Neogene conglomerates north of the Malibu Coast Fault contain clast compositions that indicate an eastern basement source terrain, and sandstone units are dominated by arkoses and arkosic wackes. South of the Malibu Coast Fault, coarse clastic interbeds contain Catalina Schist detritus as well as more-durable kinds of eastern basement clasts, and sandstone beds are generally quartz arenites. (Color publication of the map was deferred until the stratigraphic nomenclature for units in the central and western Santa Monica Mountains could be brought into conformity with the Code of Stratigraphic Nomenclature.)

1970 -- Lamar (1970) mapped and described three lithologic subdivisions in strata he assigned to the "Topanga Formation" at the east end of the Santa Monica Mountains, the southern end of the Verdugo Mountains, and the Elysian Hills, as well as an undivided subsurface "Topanga" unit at a depth of about 6,000 ft on the north flank of the Los Angeles Basin. Foraminifera and fish fossils indicate Luisian and Relizian ages for the Topanga map units; most beds appear to postdate extrusive Miocene volcanics, but some predate probable intrusive diabase. The overlying late Miocene beds are referred to the Puente Formation (Lamar, 1970).

The map and sections by Lamar (1970) indicate that the "Topanga Formation" overlaps San Gabriel Mountains basement rocks, as represented by the Wilson Quartz Diorite, and the Santa Monica Mountains basement as represented by the Santa Monica Slate. The map and section relationships indicate that significant parts of the Topanga Group section in Lamar's map area postdate much of the major fault displacement that is inferred to have resulted in the juxtaposition of the two basement terrains.

1971 - Yerkes and Campbell (1971, p. 222-223) correlated Late Cretaceous and Tertiary strata, particularly Paleogene and early Neogene shoreline facies, in the Santa Monica Mountains with those in the Santa Ana Mountains. (This work was an attempt to reconcile relations and offsets along the Malibu Coast Fault and its eastward extension, including connected structures.) They recognized correlative shoreline facies in the Vaqueros and Topanga Formations which, at that time, were equated with early and middle Miocene ages, respectively.

Subsequent paleomagnetic studies developed evidence that significant rotation of crustal blocks had occurred in the western Transverse Ranges (e.g., Kamerling and Luyendyk, 1979; Hornafius and others, 1986). The translational fault offsets proposed by Yerkes and Campbell (1971) are not, by themselves, adequate to explain the structural evolution of the present rock distribution. Although the Cretaceous, Paleogene and early Neogene shoreline correlations are probably still correct, the initial positions have not been satisfactorily reconstructed. Although the basement rocks of the Santa Ana and Santa Monica Mountains are similar, sparse paleontologic collections from the thick Jurassic slates of the two areas are, at least in part, of different ages (Jones and others, 1976), raising some uncertainty about their equivalence.)

1972 - Addicott (1972) reported his stratigraphic studies in the Temblor Range which showed the type Temblor Formation to include members as old as Refugian (early Oligocene) and as young as Relizian, spanning the age range of the entire 
"Vaqueros Stage". As a consequence, he recognized that the age range of the

"Temblor Stage" is more restricted than the age range of the Temblor Formation.

1972 - Ingle (1972) documented the paleobathymetric and paleoecological implications of the Paularino, Los Trancos, and Bommer Members of the Topanga Formation in the San Joaquin Hills area. He assigned the entire sequence to the Relizian and lower Luisian Stages.

1974 - In a landmark paper, Berggren, W.A., and Van Couvering, J.A. (1974) presented a Neogene time scale correlating zones based on planktonic microfossils, calcareous nannoplankton, radiolaria, and coccoliths with paleomagnetic reversals, European stages, New Zealand marine stages, European stages, North American Mammalian stages, and west coast (California) marine stages. The paper presents a world-wide correlation framework for the Cenozoic Period which has formed the basis for continuing work to refine and modify these correlations. California marine stages are identified with the names of the benthic foraminiferal stages erected by Kleinpell (1938); molluscan stages were not included.

1975 - Vedder (1975) revised the 1957 geologic map of the San Joaquin Hills-San Juan Capistrano area, and included expanded descriptions of the members of the Topanga Formation. He also added extensive subsurface data from wells drilled in the area (Vedder, 1975).

The Topanga Formation of Vedder (1975) in the San Joaquin Hills includes beds containing blueschist detritus, whereas the Topanga Formation of Schoellhamer and others (1981) in the northern Santa Ana Mts. does not. The earliest appearance of blueschist detritus in the San Joaquin Hills is in the Los Trancos Formation. Strata in the type locality for the Topanga Formation of Kew (1924), in the Santa Monica Mountains, do not contain blueschist detritus. In the Santa Monica Mountains, south of the Malibu Coast Fault, blueschist detritus is found in interbeds in the Monterey Shale (Mohnian and 'Relizian or Luisian') and in the underlying Trancas Formation (Saucesian and 'Relizian or Luisian'). In several places along the Malibu Coast Fault, the Trancas is juxtaposed against Topanga and Vaqueros Formation strata that do not contain blueschist detritus, and which differ in other lithologic characteristics. However, further west, in the Triunfo Pass quadrangle, detrital glaucophane is present in some sandstone beds of the Vaqueros or Topanga Canyon Formations, or both.

1976 - Campbell and Yerkes (1976) illustrate a structural disruption in strata of the Santa Monica Mountains and Simi Hills, contemporaneous with deposition of Conejo Volcanics and lower parts of the Calabasas Formation. This structural episode is approximately the same age as the "basin-inception phase" in Yerkes and others (1965) discussion of the evolution of the Neogene Los Angeles Basin.

1977 - Addicott (1977, p. 158) identifies the "Vaqueros Stage" as correlative with the upper part of the Zemorrian Stage and the lower part of the Saucesian Stage; notes that the Saucesian-Zemorrian boundary, which falls within the middle part of the "Vaqueros Stage" ...has been dated at about 22.5 m.y. B.P. (Turner, 1970)". Accordingly, he places the Oligocene-Miocene boundary within the "Vaqueros Stage" and not at the base as shown in earlier reports (such as Addicott, 1972). He notes that the "Temblor Stage" is coeval with the upper part of the Saucesian Stage, as well as the Relizian and Luisian Stages of the California foraminiferal chronology, even though previous reports regarded the "Temblor Stage" as entirely of middle Miocene age. In part, the adjustment seems a result of the 15 to 16 m.y. B.P. dating for the early-middle Miocene boundary (Berggren and Van 
Couvering, 1974; Ryan and others, 1974), which would also make the lower part of the "Temblor Stage" early Miocene in age. Addicott (1977) establishes significant changes in the time scale for the molluscan stages. However, changes like this can take a variable number of years to affect subsequent publications by different authors.

Addicott (1977, p. 157) identifies the "California Neogene Stages" as "unnamed", "Vaqueros", "Temblor", "Margaritan", "Jacalitos", "Etchegoin", and "San Joaquin"; referring to each as a Stage. He used quotation marks for the stage names to avoid confusion with formations bearing the same names.

1979 - Yerkes and Campbell (1979) elevated the Topanga formation to Group status and assigned formation names that meet the criteria of the 1961 and subsequent versions of the North American Code of Stratigraphic Nomenclature (American Commission on Stratigraphic Nomenclature, 1961; American Commission on Stratigraphic Nomenclature, 2005). They identified significant differences in lithofacies among the three formations; i.e.: the lower unit, the Topanga Canyon Formation, is dominated by a westward-deepening marine shelf depositional environment, contains a distinctive mollusk fauna, and has been variably affected by intrusive dikes and sills related to the overlying volcanics; the middle unit, the Conejo Volcanics, is chiefly extrusive basalt and andesite, much of which was erupted into a submarine environment; the upper unit, the Calabasas Formation, is dominated by bathyal fan turbidites with interbedded silty shales, and is lithologically distinct from the pre-volcanic strata. The Calabasas Formation is generally not intruded by the basalt and diabase that commonly intrudes the prevolcanic and syn-volcanic Topanga Group strata. However, the low-angle Malibu Bowl fault, which carries Calabasas strata in its upper plate, appears to be intruded by basalt along the west side of Malibu Canyon and in many places to the east, between Malibu and Santa Ynez Canyons. Many Calabasas sandstones and conglomerates contain significant proportions of detrital volcanic (andesitic and basaltic) rock fragments.

Near Agoura, the lower part of the Calabasas Formation contains a few discontinuous masses of basalt and andesite, some of which are flows and volcaniclastic beds, and none show clear evidence of intrusive origin. The relations in the eastern Santa Monica Mountains, where volcanics are discontinuous and may not be directly related to the Triunfo Pass-Conejo Grade eruptive center for the Conejo Volcanics, have not been determined. Hoots (1931) did not discriminate extrusive from intrusive volcanics and mapped both pre- and post-volcanic sedimentary strata as Topanga Formation. Future mapping should attempt to discriminate post-volcanic from pre-volcanic sedimentary strata to assist in correlating the subunits of the Topanga Group in eastern Santa Monica Mountains with the formations identified to the west.

Sedimentary breccias containing reworked fossils (including clasts of sandstone with imbedded Paleocene, Eocene, and Miocene mollusks) have been mapped in the Calabasas Formation; locally, they also contain basaltic and andesitic volcanic clasts derived from the Conejo Volcanics and large clasts of red sandstone and conglomerate derived from the Sespe Formation. Sedimentary breccias occur at more than two stratigraphic levels within the formation (Yerkes and Campbell, 1979; Yerkes and Campbell, 1980; Campbell and others, 1996). Many of the reworked fossil mollusk specimens show well-preserved form and ornamentation. 
Only one assemblage of possibly unreworked middle Miocene mollusks is known from the Calabasas Formation in the Santa Monica Mountains, and most of the Calabasas foram collections have not yielded assemblages diagnostic of a single stage; they are reported as "middle Miocene, Relizian or Luisian". One well-documented Luisian foram assemblage was reported from near the base of the Calabasas at a locality east of Russell Valley and south of the Ventura Freeway. One unqualified and one questioned Mohnian assemblage were collected in the area west of Topanga Canyon Boulevard from Calabasas strata that lie below the basal Modelo unconformity as extended west (see Yerkes and Campbell, 1980) from the exposure that Hoots (1931) mapped from Topanga Canyon Boulevard eastward. (The unconformity exposed on Topanga Canyon Boulevard was subsequently used by Kleinpell (1938) as the base of his type Mohnian Stage.)

1980 - The stratigraphic nomenclature proposed by Yerkes and Campbell (1979) was applied to a geologic map of an area combining the Malibu Beach and western part of the Topanga 7.5' quadrangles (Yerkes and Campbell, 1980). That map refers the Topanga Group to Middle Miocene and the Vaqueros Formation to Lower Miocene (Yerkes and Campbell, 1980). Users of the map should be aware that the age assignments should be revised to accommodate updates to the geologic time scale (see fig. 3.)

1981 - Schoellhamer and others (1981) describe the geology of the northern Santa Ana Mountains (most of their field mapping and laboratory work was done in the 1950's and 1960's.) They refer to the Topanga as a formation, and note that the Topanga Formation contains a molluscan fauna of "provincial middle Miocene age." Sparse microfossil collections were questionably referred to the Relizian Stage of Kleinpell (1938). Their generalized section (Schoellhamer and others, 1981, Figure 3, p. D-5) places the locally unconformable base of the Topanga Formation at the base of the middle Miocene series, and equates the unconformity at the base of the overlying Puente Formation with the top of the middle Miocene series. Underlying strata, consisting of interbedded marine and nonmarine beds of late Eocene (?) to early Miocene age, were mapped together as "Sespe and Vaqueros Formations, undifferentiated." (In a 2006 written communication, McCulloh reports that subsurface data from the area west of the northern Santa Ana Mountains indicate that equivalent beds there include microfossils as old as the Saucesian BFS, early Miocene.)

The description of lithologies in the Topanga Formation makes no mention of detrital glaucophane, or of schistose clasts derived from the Catalina Schist. However, they describe glaucophane schist detritus in the Soquel Member of the overlying Puente Formation.

1981 - Poore, Barron, and Addicott (1981) present a revised correlation of provincial molluscan stages for California that restricts the "Vaqueros Stage" to early Miocene, extends the succeeding "Temblor Stage" to early and middle Miocene, in turn succeeded by the "Margaritan Stage" of middle and late Miocene age.

1986 -- Hornafius and others (1986) summarized paleomagnetic evidence of rotation and ages of rotated rocks for the western Transverse Ranges. From plots showing ages of rocks sampled against paleomagnetic declination, they conclude (p. 1482) that rapid clockwise rotation of 50-60 degrees occurred throughout the western Transverse Ranges in middle Miocene time (1-16 m.y.). Using the correlations of Barron and Isaacs (2001), this would indicate that the deposition of the latest 
Relizian through early Mohnian parts of the Topanga Group were being deposited while rotation was occurring, and that rotation may have continued during deposition of the late Miocene parts of the Modelo, Puente, and Monterey Formations.

1987 -- Henry (1987, p. 3) indicates that four of the 62 Los Angeles Basin oilfields produced from the Topanga Formation. It is not clear whether the four include the Huntington Beach and Wilmington fields, where Wissler indicates the Luisian age beds are better correlated with the Monterey Formation. In his series of paleogeographic diagrams, Henry shows both Relizian and Luisian intertidal shelf deposition over the areas of most of the Los Angeles Basin fields, except for the west side fields north and northwest of Wilmington and south of Inglewood. Along the Newport-Inglewood zone, he shows Relizian present in the Potrero field (but the basis is not clearly cited) and absent to the south and west. The Luisian also is apparently absent from the Potrero field. The diagrams also indicate that both Relizian and Luisian are absent in the southwestern part of the West Newport field, an area contiguous with the San Joaquin Hills.

1990-1993 - Dibblee and Ehrenspeck (1990, 1992a, 1992b, 1992c, 1993a.1993b) geologic maps in the central and western Santa Monica Mountains refer the Modelo Formation and parts of the Calabasas Formation (in the nomenclature of Yerkes and Campbell, 1979) to the Monterey Formation, obscuring lithologic differences with the Monterey Formation which crops out south of the Malibu Coast Fault. They referred parts of the Calabasas Formation of Yerkes and Campbell (1979) to the "Upper Topanga Formation" and, in eastern areas where volcanics are discontinuous, include parts of the Calabasas Formation and Conejo Volcanics of Yerkes and Campbell (1979) as part of a "Middle Topanga Formation." They did not recognize a distinction between the Topanga Canyon and Vaqueros Formations of Yerkes and Campbell (1979), and referred the combined Topanga Canyon and Vaqueros Formations to a "Lower Topanga Formation." Although their usage resembles the "Upper, Middle, and Lower Topanga Formations" nomenclature of Durrell (1954), the map units are not everywhere the same. As with the nomenclature proposed by Durrell (1954), the use of "Upper", "Middle", and "Lower" as an intrinsic part of a formation name does not follow the guidelines of the North American Stratigraphic Code, which was first published in 1961 and most recently updated in 2005 (The North American Commission on Stratigraphic Nomenclature, 2005). Dibblee and Ehrenspeck (1993c) also assign pre-Monterey strata to the south of the Malibu Coast Fault to the "Upper Topanga Formation", including beds with Catalina Schist detritus (San Onofre Breccia), which are interbedded with mudstone containing Saucesian BFS foraminifera, and to dolomitic and cherty marls assigned to the Monterey Shale by Yerkes and Campbell (1979).

1991 - Smith's (1991) geochronology of giant pectinids places Vertipecten kernensis (Hertlein) in the "Vaqueros Stage" (Smith, 1991, Fig. 10). This species is abundant at the horizon taken by Yerkes and Campbell as the base of the Topanga Canyon Formation in the Santa Monica Mountains.

1991 - In his review of the Neogene stratigraphy of the Los Angeles Basin, Blake (1991) uses "Topanga Group" in the sense of Yerkes and Campbell (1979) for columns in the Santa Monica Mountains, San Joaquin Hills, Puente Hills, and Santa Ana Mountains, western Los Angeles Basin subsurface, and eastern Los Angeles Basin subsurface. Where not subdivided, "Topanga Group" is substituted for 
“Topanga Formation”. He designates (Table 3) Paularino, Los Trancos, and Bommer as Formations in the Topanga Group. Ages are listed as: Paularino, middle to early Miocene (lower Luisian to upper Relizian Stages), Los Trancos, early Miocene (Relizian Stage), Bommer, early Miocene (Relizian Stage). In the text description (p. 143-146) however, he continues to use their old designation as "Members".

Blake's Figure 2 (p.139) correlates sections for the Santa Monica Mountains, Palos Verdes Hills, San Joaquin Hills, Puente Hills-Santa Ana Mountains area, west side Los Angeles Basin subsurface, and east side Los Angeles Basin subsurface. Blake's sections show the Zemorrian Stage at the top of the Oligocene, the Saucesian Stage as the lower part of the early Miocene, the Relizian Stage as mostly early Miocene but partly middle Miocene, the Luisian Stage as middle Miocene, and the Mohnian Stage as middle and late Miocene. 1991 - Wright's (1991) summary of the structural geology and tectonic evolution generally agrees with the usage of Blake in the same volume; i.e., he uses Topanga Group, except that some sections and an Appendix listing stratigraphic terms use "Topanga Formation", and he includes the Bommer, Los Trancos, and Paularino as "Members" (Wright, 1991). Wright (1991, Fig. 5, p. 42) also illustrated the extent and thickness of the Topanga Group in and around the margins of the Los Angeles Basin. In his discussion of the Topanga Group, Wright (1991, p. 43) discusses "Predecessor Basins" as including:

a) "...the Late Cretaceous and Paleogene fore-arc basins that extended along the entire western edge of the North American plate. Figure 4 (p. 42) shows the known distribution of this sequence (designated as "Sedimentary") in the Los Angeles area. Its presence or absence beneath the deeper parts of the present Los Angeles Basin has not yet been demonstrated."

b) "... volcanic and sedimentary rocks (the Topanga Group of Figure 5) (p. 42) deposited during the early to middle Miocene rifting that opened the basins of the borderland province and rotated the blocks within the Transverse Ranges."

c) "... regional subsidence during the late middle and late Miocene that facilitated the widespread deposition of biogenic sediments and clays of the Monterey and related formations."

Wright concludes that the basin inception may have begun as early as the Zemorrian Stage, early Miocene, and that volcanism, rifting, and rotation all occurred during Topanga Group deposition. (However, most of the rotation paleomagnetic data are from volcanic rocks, indicating that they record only postvolcanic rotation. If rotation began before volcanism, the measured rotations are minima.)

1991 --Yeats and Beall (1991, p. 222) cite the usage of Barbat (1958) in restricting their usage of the term "Los Angeles Basin" to "...the structural configuration that was not fully achieved until close to the beginning of Repetto deposition, about $4 \mathrm{Ma}$, although the central trough first appeared during the late Mohnian, about $8 \mathrm{Ma}$."

The emphasis of the Yeats and Beall paper is on the Pico Formation stratigraphy, late Miocene to early Pliocene, but in summarizing the pre-basin stratigraphy of the area the "Topanga Formation" is grouped with older (Paleogene and early Miocene) strata as showing “...no tendency to thicken toward the center of the Los Angeles Basin."

1992 -- Bartow (1992) compiled Paleogene and Neogene time scales for southern California and shows the base of the Miocene at nearly $24 \mathrm{Ma}$, above the base of 
the "Vaqueros Stage" (about $30 \mathrm{Ma}$ ); it places the "Vaqueros-Temblor" boundary between $17 \mathrm{Ma}$ and $18 \mathrm{Ma}$; and shows the top of the "Temblor Stage" between 13 $\mathrm{Ma}$ and $14 \mathrm{Ma}$, at about the top of the Luisian benthic foramiferal Stage.

1993 - In a guidebook article and map, Dibblee and Ehrenspeck (1993c) extend Topanga terminology to strata south of the Malibu Coast Fault, applying the term "Upper Topanga Formation" to mudstone and sandstone called "Trancas Formation" by Yerkes and Campbell (1979) and to dolomitic and cherty marls assigned to the Monterey Shale by Yerkes and Campbell (1979). They also do not recognize the Zuma Volcanics of Yerkes and Campbell (1979) as associated with a different suite of strata than the Conejo Volcanics, extending the term "Conejo Volcanics" to volcanic rocks south of the Malibu Coast Fault. However, they retain "Monterey Formation" for some strata on Point Dume.

The usage of Dibblee and Ehrenspeck (1993c) would extend the age of the "Upper Topanga Formation" (Calabasas Formation) downward from the Luisian BFS to include strata containing Relizian BFS and Saucesian BFS foraminifera. In addition, assigning Mohnian BFS strata (Modelo Formation) on the north flank of the Santa Monica Mountains to the "Monterey Formation" blurs distinctions of the age and provenance of both units.

1993 - Fritsche (1993) proposed a stratigraphic nomenclature that combines the sandstone members of the Vaqueros and Topanga Canyon Formations of Yerkes and Campbell (1979) together as an "Unnamed Sandstone." He also proposed combining the Encinal Member of the Topanga Canyon Formation with the Danielson Member of the Vaqueros Formation to be termed the "Rincon Shale", with a "Danielson Tongue" below a lower Miocene tongue of the "Unnamed Sandstone", and an "Encinal Tongue" above it. Fritsche does not address the stratigraphy south of the Malibu Coast Fault.

Although not explicitly stated, the effect of Fritsche's proposal would be to abandon the allostratigraphic limits of the Topanga Formation as defined by Kew (1924), except for a very restricted part of the Topanga Canyon Formation of the Topanga Group of Yerkes and Campbell (1979). His proposed combination of the Vaqueros and Topanga Canyon Formations (based on lithologic similarities) does not recognize mappable field relations - that the stratigraphic sequence can be consistently identified from the molluscan assemblages they contain, and a horizon separating the two can be mapped using the continuity of overlapping individual beds. His proposal also leads to a sequence wherein Rincon Shale lies below sandstone carrying "Vaqueros" CMS mollusks; however, in the type area for the Rincon, in the Santa Ynez Mountains, the Rincon lies entirely above recognized "Vaqueros" CMS strata.

1996 - Campbell and others (1996) use the nomenclature of Yerkes and Campbell (1979), Vaqueros Formation and Topanga Group, for map units in the Point Dume quadrangle geologic map. They also used the age assignments of Yerkes and Campbell (1979); i.e., the Vaqueros Formation is identified as lower Miocene and the Topanga Group is labeled middle Miocene. (An updated age assignment for the Vaqueros Formation is early Miocene, Oligocene, and late Eocene; and the Topanga Group ranges in age from early Miocene to late Miocene.)

1998 - Atwater and Stock (1998) update Miocene plate motions and correlations with evolution of southwest North American structure; their calculations of PacificAntarctic-Africa-North America plate circuit yield reconstructions for times since chron 13 (33 Ma). Their quantitative comparison of reconstructed oceanic plate 
motions to structural displacements within the continental plate in the southwestern U.S. shows that the attachment of the Salinian Block to the Pacific plate was probably not completed until about chron $5 \mathrm{E}(\sim 18 \mathrm{Ma})$, even though the breakup of the Farallon plate probably began at about $28 \mathrm{Ma}$ (Atwater and Stock, 1998, p. 391).

The $\sim 18 \mathrm{Ma}$ age is contemporaneous with the "Vaqueros-Temblor" CMS boundary suggested by Bartow (1992) and reported by McCulloh and others (2002, fig. 4; reproduced herein as fig. 3). It approximates the beginning of deposition of the Topanga Group.

2000 - McCulloh and others (2000) conclude that outcrop and subsurface data on the distribution of Paleogene depositional environments in the area that now adjoins the northeastern part of the Los Angeles Basin indicate a nearly east-west trend for the base-of-Neogene unconformity that marks the depositional edge of the Los Angeles Basin. This appears to be well south of the rock boundary between the Peninsular Ranges and San Gabriel basement complexes as mapped by Morton and Miller (2003), and indicates a pre-Miocene topographic configuration that is more complex than a simple, continuous, southwest-facing shelf.

2001 - McCulloh and others (2001) use the term "Topanga Group of Wright (1991)" and indicate that it may not be the exact stratigraphic equivalent of the "Topanga Group of Yerkes and Campbell (1979)". They identify the middle Miocene volcanic rocks of the northeastern Los Angeles Basin (chiefly basalt and basaltic andesite, rarely more-silicic volcanic rocks) as part of the "Topanga Group" as used by Wright (1991).

In a careful reconstruction of the northeastern margin of the Los Angeles Basin, using outcrop and subsurface data, McCulloh and others (2001) conclude that the Mountain Meadows Dacite of the San Jose Hills is consanguineous and contemporary (Oligocene) with many intrusive bodies in the eastern San Gabriel Mountains. Therefore, its' area of emplacement transcends the (suture) boundary between the Mesozoic basement terrain of the Peninsular Ranges and the preCambrian-Mesozoic basement terrain of the San Gabriel Mountains. The reconstruction indicates that Paleocene and late Luisian BFS shorelines lie in approximately the same positions, but with the late Luisian BFS shoreline more embayed to the northeast (see their Figure 11).

2001 - Barron and Isaacs (2001) updated the chronostratigraphic framework for the California Miocene, indicating that an early Miocene age for a significant part of the Relizian benthic foraminiferal Stage and a middle Miocene age for a significant part of the Mohnian benthic foraminiferal Stage were firmly established.

2002 -- McCulloh and others (2002) apply the geologic time framework of Barron and Isaacs to correlate isotope ages of volcanic rocks with early, middle, and late subdivisions of the Miocene Epoch, published and new isotope ages (Ma), magnetic chronology and polarity, calcareous nannofossil zones, benthic foraminiferal stages, provincial molluscan stages, and terrestrial vertebrate stages (fig. 3).

The correlation chart (fig. 4, p. 10 of McCulloh and others, 2002; reproduced here as fig. 3) indicates that the "Vaqueros-Temblor" CMS boundary falls at about 17.6 Ma, which is near the middle of the late Saucesian benthic foram Stage. It shows the Saucesian-Relizian boundary at about $17.1 \mathrm{Ma}$, the Relizian-Luisian boundary at 15.7 Ma, and the Luisian-Mohnian boundary at 
about 13.6 Ma. It places the boundary between early and middle Miocene at 16.4 $\mathrm{Ma}$, and the boundary between middle and late Miocene at 11.2 Ma. From this, the age of the Topanga Group is inferred to range from as old as late Saucesian BFS ( 17.6 Ma) to as young as late Luisian BFS ( 13.6 Ma).

2003 - The compilation by Morton and Miller (2003) of the San Bernardino 30' x 60' quadrangle avoids use of Topanga (whether Formation or Group) by assigning rocks in the vicinity of Azusa to "sedimentary rocks of the Azusa area." Earlier workers (e.g., Shelton, 1955) had referred the sequence to the Topanga Formation. The rocks consist of sandstone, conglomerate, and interbedded siltstone and shale with basalt. Some sandstone beds contain Turritella ocoyana and finer-grained interbeds have yielded Luisian BFS foraminifers.

2004 - Morton's geologic map (Morton, 2004) of the Santa Ana 30’ x 60' quadrangle uses "Topanga Formation." Because the three members of the Topanga Formation in the Santa Ana 30'x 60' quadrangle, have not been correlated with the Topanga Group formations recognized by Yerkes and Campbell (1979) he chose to retain the nomenclature of the source maps for the Santa Ana quadrangle.

2004 - McCulloh and Beyer (2004) use formation nomenclature of various authors in different localities, and do not discuss the Topanga Group as a stratigraphic unit. In their Northwest Sector, the central and western Santa Monica Mountains sections do not extend above the Conejo Volcanics and do not include the Calabasas Formation, which is the uppermost formation in the type Topanga Group of Yerkes and Campbell (1979). In the western Santa Monica Mountains, lower and middle Miocene strata are referred to the Vaqueros Formation, the Lower Topanga Formation, and to the Conejo Volcanics. In the central Santa Monica Mountains, lower and middle Miocene rocks are referred to the Vaqueros and Topanga Canyon Formations, and to the Conejo Volcanics. In the eastern Santa Monica Mountains, middle Miocene strata are assigned to the Topanga Formation, for which the base rests on volcanic beds having isotope ages that predate those of the oldest Conejo Volcanics.

The Modelo Formation, which lies unconformably above the type Topanga Group (Yerkes and Campbell, 1979) in the central Santa Monica Mountains, is not shown on the sections for the central Santa Monica Mountains, but is shown as unconformably above the Topanga (Group?) in the section for the eastern Santa Monica Mountains (McCulloh and Beyer, 2004, fig. 2, p. 3). In their Southeast Sector, the Topanga Formation and "Topanga with volcanics" are overlain by the Puente Formation (middle and late Miocene), or by Monterey Shale (middle Miocene) succeeded by Puente Formation (middle and late Miocene), are shown extending downward to include early Miocene strata. The Vaqueros Formation in the Santa Ana Mountains and the San Joaquin Hills may not extend below the (ca. 24 ma) Oligocene-Miocene boundary.

McCulloh and Beyer (2004, Fig. 2, p. 3) show the "Vaqueros-Temblor" Stage boundary at about 19.5 Ma, and the "Temblor-Margaritan" Stage boundary at about $12 \mathrm{Ma}$. The early Miocene is shown ranging from about $24 \mathrm{Ma}$ to about 16.5 Ma, and the middle Miocene from about 16.5 Ma to about 11 Ma. They put the Vaqueros Formation in early Miocene and the pre-Conejo parts of the Topanga Group (Formation) almost entirely in early Miocene, though the uppermost parts of the pre-Conejo Topanga strata may extend into the middle Miocene. The Conejo Volcanics is shown with a base at about 16.5 Ma and a top at about 13.5 Ma in the central and western Santa Monica Mountains. The age of 
the oldest and youngest of the Conejo Volcanics varies from place to place within the Santa Monica Mountains, and the actual range may be greater than is indicated by the limited number of localities that have yielded isotope ages.

2005 - Yerkes and Campbell, in their (2005) compilation of the geology of the 30' x 60' Los Angeles quadrangle, refer the Topanga Group to the middle Miocene; but the Calabasas Formation (the uppermost formation in the Topanga Group) is referred to early late Miocene and late middle Miocene. The Conejo Volcanics is referred to the mid-middle Miocene, and the Topanga Canyon Formation is referred to early middle Miocene. The Vaqueros Formation is referred to early Miocene. (An updated age assignment for the Vaqueros Formation is early Miocene, Oligocene, and late Eocene; and the Topanga Group ranges in age from early Miocene to late Miocene.) Their map (Yerkes and Campbell, 2005) shows that the base of the Calabasas Formation is of different ages in different areas. In the area south and west of Calabasas, the formation is thick, basal beds are nearly accordant with the underlying Conejo Volcanics (minor discordance could reflect deposition on an uneven surface of volcanic deposits), and there is no clear evidence of subaerial erosion of the underlying volcanics. South and west of Agoura the Calabasas Formation appears generally accordant with the underlying Conejo, but is much thinner; and further west, at Westlake Village and Thousand Oaks, the base is a volcaniclastic conglomerate. A similar conglomerate is also mapped along the south flank of the Simi Hills, where the contact is strikingly discordant with underlying Cretaceous sandstone and conglomerate.

2006 - Morton and Miller (2006) discuss the Topanga Group in their description of the map units in the combined San Bernardino-Santa Ana 30' x 60' quadrangles.

In the San Joaquin Hills, Morton and Miller (2006) have followed the usage of Blake (1991, Fig. 2, p. 139) in using the term Topanga Group. Morton and Miller (2006) also elevated the three members identified by Vedder and others (1957), to formation rank as the Paularino, Los Trancos, and Bommer Formations.

Elsewhere, they describe the Topanga Group in the Azusa area of the San Gabriel Valley as consisting of mostly marine sandstone and conglomerate that locally includes volcanic rocks. In an earlier publication (Morton and Miller, 2003) they referred to these rocks as "sedimentary rocks of the Azusa area." The section in the Azusa area is about $760 \mathrm{~m}$ thick (Shelton, 1955), and includes conglomeratic beds having clasts as large as about $1 \mathrm{~m}$. Most of the clasts resemble rocks in the adjacent San Gabriel Mountains, and some volcanic rock clasts resemble the Glendora Volcanics. Most of the exposed rocks are coarsegrained sandstone, some of which are cross-bedded, fine-grained, thin-bedded sandstone and siltstone, and diatomaceous, fissile, and partly silicified shale. Fine-grained rocks contain foraminifers indicative of the Luisian BFS and the highest beds contain fish scales that probably are uppermost Luisian or lowermost Mohnian (Shelton, 1955). The section also includes a basalt layer about $30 \mathrm{~m}$ thick (Shelton, 1955); this mappable basalt unit, where well exposed, consists of pillow basalt (Photo 219 in the report by Morton and Miller, 2006) indicating a submarine origin. This basalt appears similar to pillow basalts included within the Conejo Volcanics of Yerkes and Campbell (1979) in the Santa Monica Mountains.

Most of the Topanga Group in the South Hills, just south of Glendora, is massive and well bedded sandstone that commonly contains conglomerate lenses. 
It is about $600 \mathrm{~m}$ thick, about 35 to 40 percent of which consists of interbedded Glendora Volcanics.

\section{Acknowledgments}

Many workers have contributed to the literature and unpublished discussions describing the stratigraphy and spatial distribution of the Topanga Group and associated strata. The references that are cited in the above chronology are a small sample; they were selected to represent our view of how the current stratigraphic nomenclature developed. Over the past five decades, continuing discussions with our late colleague, Robert F. Yerkes, have had a strong influence on our perceptions. We wish to thank F. K. Miller, D. M. Morton, and C. L. Powell, II, for thoughtful and constructive reviews. Rachel M. Alvarez kindly provided the digital shaded relief map we annotated for an index (fig. 1). The work was supported by the U.S. Geological Survey, Western Earth Surface Processes Project, Basin and Landscape Co-evolution (BALANCE).

\section{References Cited}

Addicott, W.O., 1972, Provincial middle and late Tertiary molluscan stages, Temblor Range, California: Society of Economic Paleontologists and Mineralogists, Pacific Section, Pacific Coast Miocene Biostratigraphic Symposium, Bakersfield, California, 1972, Proceedings, 26 p., 4 pls.

Addicott, W.O., 1977, Neogene chronostratigraphy of nearshore marine basins of the eastern North Pacific. International Congress on Pacific Neogene Stratigraphy, $1^{\text {st }}$, Tokyo, 1976, Proceedings. Tokyo, Kaiyo Shuppan Co., p. 151-175.

American Commission on Stratigraphic Nomenclature, 1961, Code of Stratigraphic Nomenclature: American Association of Petroleum Geologists Bulletin, v. 45, no. 5, p. 645-665.

Arnold, Ralph, 1907, New and characteristic species of fossil mollusks from the oilbearing Tertiary formations of southern California: U.S. National Museum Proceedings, v. 32, p. 525-560.

Atwater, Tanya, 1970, Implications of plate tectonics for the Cenozoic tectonic evolution of western North America: Geological Society of America Bulletin, v. 81, p. 3513-3535.

Atwater, Tanya, and Stock, Joann, 1998, Pacific-North American plate tectonics of the Neogene southwestern United States, an update: International Geology Review, v. 40, p. $375-402$.

Barbat, W.F., 1958, The Los Angeles basin area, California, in A guide to the geology and oil fields of the Los Angeles and Ventura regions, American Association of Petroleum Geologists Annual Meeting, March 1958, p. 62-77.

Barron, J.A., and Isaacs, C.M., 2001, Updated chronostratigraphic framework for the California Miocene, in Isaacs, C.M., and Rullkötter, Jürgen, eds., The Monterey Formation from Rocks to Molecules: New York, Columbia University Press, p. 393-395.

Bartow, J.A., compiler, 1992, Paleogene and Neogene time scales for southern California: U.S. Geological Survey Open-File Report 92-212, 2 diagrams (see http://pubs.er.usgs.gov/usgspubs/ofr/ofr92212). 
Berggren, W.A., and Van Couvering, J.A., 1974, The late Neogene: biostratigraphy, geochronology and paleoclimatology of the last 15 million years in marine and continental sequences: Palaeogeography, Paleoclimatology, Paleoecology, v. 16, no. $1 / 2$, p. 1-216.

Berry, A.L., Dalrymple, G.B., Lanphere, M.A., and VonEssen, J.C., eds., 1976, Summary of miscellaneous potassium-argon age measurements, U.S. Geological Survey, Menlo Park, California, for the years 1972-74: U.S. Geological Survey Circular 727, 13 p. (see http://pubs.er.usgs.gov/usgspubs/cir/cir727)

Blackerby, B.A., 1965, The Conejo Volcanics in the Malibu Lake area of the western Santa Monica Mountains, Los Angeles County, California: Unpublished PhD thesis, University of California, Los Angeles, 157 p., map scale 1:12,000.

Blake, G.H., 1991, Review of the Neogene biostratigraphy and stratigraphy of the Los Angeles Basin and implications for basin evolution; in Biddle, Kevin T., ed., 1991, Active Margin Basins; American Association of Petroleum Geologists Memoir 52, p. 135-184.

Campbell, R.H., Yerkes, R.F., and Wentworth, C.M., 1965, Detachment faults in the central Santa Monica Mountains, in, Geological Survey Research 1966: U.S. Geological Survey Professional Paper 550-C, p. C1-C11.

Campbell, R. H., and Yerkes, R. F., 1976, Cenozoic evolution of the Los Angeles Basin area--relation to plate tectonics; in Howell, D. G., ed., Aspects of the geologic history of the California Continental Borderland: Pacific Section, American Association of Petroleum Geologists, Miscellaneous Publications 24, p. 541-558.

Campbell , R.H., Blackerby, B.A., Yerkes, R.F., Schoellhamer, J.E., Birkeland, P.W., and Wentworth, C.M, 1970, Preliminary geologic map of the Point Dume quadrangle, Los Angeles County, California: U.S. Geological Survey Open-File Map, scale $1: 12,000$.

Campbell, R.H., Blackerby, B.A., Yerkes, R.F., Schoellhamer, J.E., Birkeland, P.W., and Wentworth, C.M., 1996, Geologic map of the Point Dume Quadrangle, Los Angeles County, California: U.S. Geological Survey Geologic Quadrangle Map GQ-1747, scale 1:24,000 (see http://pubs.er.usgs.gov/usgspubs/gq/gq1747).

Dibblee, T.W., Jr., and Ehrenspeck, H.E., 1990, Geologic map of the Point Mugu and Triunfo Pass quadrangles, Ventura and Los Angeles Counties, California: Dibblee Geological Foundation map, DF-29, map scale 1:24,000.

Dibblee, T.W., Jr., 1992a, Geologic map of the Topanga and Canoga Park (south 1/2) quadrangles, Los Angeles County, California: Dibblee Geological Foundation map, DF-35, map scale 1:24,000.

Dibblee, T.W., Jr., 1992b, Geologic map of the Calabasas quadrangle, Los Angeles and Ventura Counties, California: Dibblee Geological Foundation map, DF-37, map scale 1:24,000.

Dibblee, T.W., Jr., 1992c, Geologic map of the Malibu Beach quadrangle, Los Angeles County, California: Dibblee Geological Foundation map, DF-47, map scale $1: 24,000$.

Dibblee, T.W., Jr., and Ehrenspeck, H.E., 1993a, Geologic map of the Point Dume quadrangle, Los Angeles and Ventura Counties, California: Dibblee Geological Foundation map, DF-48, map scale 1:24,000.

Dibblee, T.W., Jr., and Ehrenspeck, H.E., 1993b, Geologic map of the Thousand Oaks quadrangle, Ventura and Los Angeles Counties, California: Dibblee Geological Foundation map, DF-49, map scale 1:24,000. 
Dibblee, T.W., and Ehrenspeck, H.E., 1993c, Field relations of Miocene volcanic and sedimentary rocks of the western Santa Monica Mountains, California, in, Weigand, P.W., Fritsche, A.E., and Davis, G.E., eds., 1993, Depositional and volcanic environments of middle Tertiary rocks in the Santa Monica Mountains, southern California: Society for Sedimentary Geology, Pacific Section, p. 75-92.

Durham, J.W., 1954, The marine Cenozoic of southern California, in Jahns, R. H., ed., 1954, Geology of southern California: California Division of Mines Bulletin 170, Chapt. III, p. 23-31.

Durham, D.L., and Yerkes, R.F., 1964, Geology and oil resources of the eastern Puente Hills area, southern California: U.S. Geological Survey Professional Paper 420-B, 62 p., map scale 1:24,000.

Durrell, Cordell, 1954, Geology of the Santa Monica Mountains, Los Angeles and Ventura Counties, Map Sheet 8, in, Jahns, R.H., 1954, ed., Geology of southern California: California Division of Mines Bulletin 170, map scale approximately $1: 125,000$.

Eaton, G.P., 1958, Miocene volcanic activity in the Los Angeles Basin, in Higgins, J.W., ed., A guide to the geology and oil fields of the Los Angeles and Ventura regions: American Association of Petroleum Geologists, Pacific Section, p. 55-61.

Eldridge, G.H., and Arnold, Ralph, 1907, The Santa Clara Valley, Puente Hills, and Los Angeles oil districts, southern California: U.S. Geological Survey Bulletin 309, $266 \mathrm{p}$.

English, W.A., 1926, Geology and oil resources of the Puente Hills region, southern California: U.S. Geological Survey Bulletin 768, 110 p., map scale 1:62,500.

Forman, J.A., 1970, Age of the Catalina Island pluton, California: Geological Society of America Special Paper 124, p. 37-45.

Fritsche, A. E., 1993, Middle Tertiary stratigraphic terminology for the Santa Monica Mountains, southern California, in, Weigand, P.W., Fritsche, A.E., and Davis, G.E., eds., Depositional and volcanic environments of middle Tertiary rocks in the Santa Monica Mountains, southern California: Society for Sedimentary Geology, Pacific Section, Book 72, p. 1-12.

Gale, Hoyt S., 1932, International Geological Congress, XVI session, United States, 1933, Guidebook 15: Excursion C-1, Southern California: United States Government Printing Office, Washington, D.C., 68 p. (includes contributions by W.P. Woodring, L.F. Noble, Chester Stock, H.W. Hoots, R.D. Reed, and W.S.W. Kew).

Henry, M.J., 1987, Los Angeles Basin - an overview, in, Clarke, D.D., and Henderson, C.P., eds., Geologic field guide to the Long Beach area: Pacific Section, American Association of Petroleum Geologists, p. 1-29.

Hoots, H.W., 1931, Geology of the eastern part of the Santa Monica Mountains, Los Angeles County, California: U.S. Geological Survey Professional Paper 165-C. 134 p., map scale 1:24,000.

Hornafius, J.S., Luyendyk, B.P., Terres, R.R., and Kamerling, M.J, 1986, Timing and extent of Neogene tectonic rotation in the western Transverse Ranges, California: Geological Society of America Bulletin, v. 97, p. 1476-1487 
Ingle, J. C., Jr., 1972, Biostratigraphy and paleoecology of early Miocene through early Pleistocene benthonic and planktonic foraminifera, San Joaquin Hills-Newport Bay, Orange County, California; in, Stinemeyer, E.H., ed., The Pacific Coast Miocene Biostratigraphic symposium: Pacific section, Society of Economic Paleontologists and Mineralogists, Bakersfield, California, March 1972, p. 255283.

Jenkins, O.P., ed., 1943, Geologic formations and economic development of the oil and gas fields of California; California Division of Mines and Geology Bulletin 118, $773 \mathrm{p}$.

Jones, D.L., Blake, M.C., Jr., and Rangin, Claude, 1976, The four Jurassic belts of northern California and their significance to the geology of the southern California borderland, in, Howell, D.G., ed., Aspects of the geologic history of the California Continental Borderland: Pacific Section American Association of Petroleum Geologists, Miscellaneous Publication 24, p. 343-362.

Kamerling, M.J. and Luyendyk, B.P., 1979, Tectonic rotations of the Santa Monica Mountains region, western Transverse Ranges, California, suggested by paleomagnetic vectors: Geological Society of America Bulletin, Part 1, v. 90, p. 331-337, 6 figs., 3 tables.

Kew, W.S.W., 1919, Structure and oil resources of the Simi Valley, southern California: U.S. Geological Survey Bulletin 691, Contributions to Economic Geology, Part II - Mineral Fuels, p. 323-355.

Kew, W.S.W., 1923, Geologic formations of a part of southern California and their correlation: American Association of Petroleum Geologists Bulletin, v. 7, p. 411420.

Kew, W.S.W., 1924, Geology and oil resources of a part of Los Angeles and Ventura Counties, California: U.S. Geological Survey Bulletin 753, 202 p., map scale $1: 62,500$.

Kew, W.S.W., 1932, Los Angeles to Santa Barbara; in Gale, H.S., ed., 1932, Southern California: International Geological Congress, XVI session, Guidebook 15, Excursion C-1, Washington, D.C. (Government Printing Office), p. 48-68, map scale ca. 4 mi./in.

Kleinpell, R. M., 1938, Miocene stratigraphy of California: American Association of Petroleum Geologists, Tulsa, OK, London - Tomas Murby \& Co., 450 p., and 22 plates.

Lamar, D.L., 1970, Geology of the Elysian Park-Repetto Hills area, Los Angeles County, California: California Division of Mines and Geology Special Report 101, 45 p., map scale 1:24,000.

Loel, Wayne, and Corey, W.H., 1932, The Vaqueros Formation, lower Miocene of California. I Paleontology: University of California Publications, Bulletin of the Department of Geological Sciences, v. 22, p. 31-410, plates 4-65, 2 maps.

Luyendyk, B.P., Gans, P.B., and Kamerling, M.J., 1998, Geochronology of southern California Neogene volcanism, in Weigand, P.W., ed., Contributions to the geology of the Northern Channel Islands, southern California: American Association of Petroleum Geologists, Pacific Section, Miscellaneous Publication 45 , p. 9-35.

McCulloh, T.H., Beyer, L.A., and Enrico, R.J., 2000, Paleogene strata of the eastern Los Angeles basin, California: Paleogeography and constraints on Neogene structural evolution: Geological Society of America Bulletin, v. 112, p. 1155-1178. 
McCulloh, T.H., Beyer, L.A., and Morin, R.W., 2001, Mountain Meadows Dacite:

Oligocene intrusive complex that welds together the Los Angeles Basin, northwestern Peninsular Ranges, and central Transverse Ranges, California: U.S. Geological Survey Professional Paper 1649, 34 p. (see

http://geopubs.wr.usgs.gov/prof-paper/pp1649/).

McCulloh, T.H., Fleck, R.J., Denison, R.E., Beyer, L.A., and Stanley, R.G., 2002, Age and tectonic significance of volcanic rocks in the northern Los Angeles Basin, California: U.S. Geological Survey Professional Paper 1669, 24 p. (see http://geopubs.wr.usgs.gov/prof-paper/pp1669/).

McCulloh, T.H., and Beyer, L.A., 2004, Mid-Tertiary isopach and lithofacies maps for the Los Angeles region, California: templates for palinspastic reconstruction to 17.4 ma: U.S. Geological Survey Professional Paper 1690, 32 p. (see http://pubs.usgs.gov/pp/pp1690/).

Morton, D.M., and Miller, F.K., compilers, 2003, Preliminary geologic map of the San Bernardino 3o' x 60' quadrangle, California: U.S. Geological Survey Open-File Report 03-293, map scale 1:100,000 (see http://pubs.usgs.gov/of/2003/of03-293/).

Morton, D.M., compiler, 2004, Preliminary geologic map of the Santa Ana 30' x 60' quadrangle, southern California, version 2.0: U.S. Geological Survey Open-File Report 99-172, Version 2 - 2004, map scale 1:100,000 (see http://pubs.usgs.gov/of/1999/of99-172/).

Morton, D.M., and Miller, F.K., 2006, Geologic map of the San Bernardino and Santa Ana 30' x 60' quadrangles, California, with digital preparation by Cossette, P.M., and Bovard, K.R.: U.S. Geological Survey Open-File Report 2006-1217 (see http://pubs.usgs.gov/of/2006/1217/).

The North American Commission on Stratigraphic Nomenclature, 2005, American Association of Petroleum Geologists Bulletin, v. 89, p. 1547-1591, 11 Figures, 2 Tables (see http://www.agiweb.org/nacsn/code2.html).

Nourse, J.A., Weigand, P.W., and Hazelton, G.B., 1998, Igneous and tectonic response of the eastern San Gabriel Mountains to Neogene extension and rotation of the Transverse Ranges block, in Behl, R.J., ed., Guidebook of field trip \#10, $94^{\text {th }}$ Annual Meeting, Cordilleran Section: Long Beach, California, Geological Society of America, p. 10-1 to 10-15.

Oakeshott, G.B., Jennings, C.W., and Turner, M.D., 1954, Correlation of sedimentary formations in southern California, in Jahns, R.H., ed., Geology of southern California: California Division of Mines Bulletin 170, Chapter 3, p. 5-8.

Poore, R.Z., Barron, J.A., and Addicott, W.O., 1981, Biochronology of the northern Pacific Miocene: Proceedings of IGCP 114 International Workshop on Pacific Neogene Biostratigraphy, $6^{\text {th }}$ International Working Group Meeting, November 25-29, 1981, Osaka, Osaka Museum of Natural History, p. 91-98.

Ryan, W.B.F., Cita, M.B., Dreyfus Rawson, M., Burckle, L.H., and Saito, Tsunemasa, 1974, A paleomagnetic assignment of Neogene stage boundaries and the development of isochronous datum planes between the Mediterranean, the Pacific and Indian Oceans in order to investigate the response of the world ocean to the Mediterranean "Salinity Crisis": Rivista Italiana di Paleontologia e Stratigrafia, v. 80, p. 631-688. 
Saucedo, G.J., Greene, H.G., Kennedy, M.P., and Bezore, S.P., 2003, Geologic map of the Long Beach 30' x 60' quadrangle, California: California Geological Survey Regional Geologic Map Series Map No. 5, version 1.0, 2 sheets, map scale 1:100,000 (see ftp://ftp.consrv.ca.gov/pub/dmg/rgmp/Prelim_geo_pdf/lb_geol-dem.pdf).

Schoellhamer, J.E., Kinney, D.M., Yerkes, R.F., and Vedder, J.G., 1954, Geologic map of the northern Santa Ana Mountains, Orange and Riverside Counties, California: U.S. Geological Survey Oil and Gas Investigations Map OM-154, map scale $1: 24,000$.

Schoellhamer, J.E., and Yerkes, R.F., 1961, Preliminary geologic map of the coastal part of the Malibu Beach quadrangle, Los Angeles County, California: U.S. Geological Survey Open-File Map, map scale 1:12,000.

Schoellhamer, J.E., Yerkes, R.F., and Campbell, R.H., 1962, Preliminary geologic map of the coastal part of the Point Dume quadrangle, Los Angeles County, California: U.S. Geological Survey Open-File Map, map scale 1:12,000.

Schoellhamer, J.E., Vedder, J.G., Yerkes, R.F., and Kinney, D.M., 1981, Geology of the northern Santa Ana Mountains, California: U.S. Geological Survey Professional Paper 420-D, 109 p., map scale 1:24,000.

Shelton, J.S., 1955, Glendora volcanic rocks, Los Angeles Basin, California: Geological Society of America Bulletin, v. 66, p. 45-90.

Smith, J.T., 1991, Cenozoic giant pectinids from California and the Tertiary Caribbean Province: Lyropecten, "Macrochlamys," Vertipecten, and Nodipecten species: U.S. Geological Survey Professional Paper 1391, 156 p., 38 plates.

Soper, E.K., 1938, Geology of the central Santa Monica Mountains: California Journal of Mines and Geology, v. 34, p. 131-180, map scale ca. 1:36,200.

Sullwold, H.H., Jr., 1960, Tarzana Fan, deep submarine fan of late Miocene age, Los Angeles County, California: American Association of Petroleum Geologists Bulletin, v. 44, p. 433-457.

Susuki, Takeo, 1951, Stratigraphic paleontology of the Topanga Formation at the type locality, Santa Monica Mountains, California: unpublished MA thesis, University of California, Los Angeles, 85 p., map scale 1:12,000.

Taliaferro, N.L., 1924, Notes on the geology of Ventura County, California, in Taliaferro, N.L., Hudson, F.S., and Craddock, W.N., the oil-fields of Ventura County, California: American Association of Petroleum Geologists Bulletin, v. 8, p. 789810.

Tedford, R.H., Skinner, M.F., Fields, R.W., Remsberger, J.M., Whistler, D.P., Galusha, Theodore, Taylor, B.E., McDonald, J.R., and Webb, S.D.,1987, Faunal succession and biochronology of the Arikareean through Hemphillian interval (late Oligocene through earliest Pliocene epochs) in North America, in Woodburne, M.O., ed., Cenozoic mammals of North America: Berkeley, University of California Press, p. 153-210.

Turner, D.L., 1970, Potassium-argon dating of Pacific coast Miocene foraminiferal stages, in, Bandy, O.L., ed., Radiometric dating and paleontologic zonation: Geological Society of America Special Paper 124, p. 91-129.

Vedder, J.G., Yerkes, R.F., and Schoellhamer, J.E., 1957, Geologic map of the San Joaquin Hills-San Juan Capistrano area, Orange County, California: U.S. Geological Survey Oil and Gas Investigations, Map OM 193, map scale 1:24,000. 
Vedder, John G., 1975, Revised geologic map of the San Joaquin Hills-San Juan Capistrano area, Orange County, California: U.S. Geological Survey Open-File Report 75-552, 49 p., map scale 1:24,000, in 5 sheets.

Vedder, J.G., and Howell, D.G., 1976, Review of the distribution and tectonic implications of Miocene debris from the Catalina Schist, California continental Borderland and adjacent coastal areas, in Howell, D.G., ed., Aspects of the Geologic History of the California continental Borderland, American Association of Petroleum Geologists, Pacific Section, Miscellaneous Publication 24, p. 236340.

Vedder, J.G., Howell, D.G., and Forman, J.A., 1979, Miocene strata and their relation to other rocks, Santa Catalina Island, California, in Armentrout, J.M., Cole, M.R., and TerBest, H., Jr., eds., Cenozoic paleogeography of the western United States: Los Angeles, Society of Economic Paleontologists and Mineralogists, Pacific Section, P. 239-256.

Weaver, C.E., chairman, and others, 1944, Correlation of the marine Cenozoic formations of western North America: Geological Society of America Bulletin, v. 55, p. 569598.

Weigand, P. W., 1982, Middle Cenozoic volcanism of the western Transverse Ranges, in Fife, D.L., and Minch, J.A., eds., Geology and mineral wealth of the California Transverse Ranges, Santa Ana, California, South coast Geological society, Inc., p. 170-188.

Wissler, Stanley G., 1943, Stratigraphic formations of the producing zones of the Los Angeles Basin oil fields, in: Jenkins, O. P., ed., Geologic formations and economic development of the oil and gas fields of California; California Division of Mines and Geology Bulletin 118, p. 209-234.

Woodford, A.O., Schoellhamer, J.E., Yerkes, R.F., and Vedder, J.G., 1954, Geology of the Los Angeles Basin, in Jahns, R. H., ed., 1954, Geology of southern California: California Division of Mines Bulletin 170, Chapter II, p. 65-81, 2 plates (Plate 1, geologic map) scale approximately 1:95,000.

Woodring, W.P., Bramlette, M.N., and Kew, W.S.W., 1946, Geology and paleontology of Palos Verdes Hills, California: U.S. Geological Survey Professional Paper 207, 145 p., map scale 1:24,000.

Wright, T.L., 1991, Structural geology and tectonic evolution of the Los Angeles Basin, California; in Biddle, Kevin T., ed., 1991, Active Margin Basins; American Association of Petroleum Geologists Memoir 52, p. 35-134.

Yeats, Robert S., 1973, Newport-Inglewood Fault Zone, Los Angeles Basin, California: American Association of Petroleum Geologists Bulletin, v. 57, p. 117-135, 5 Figs., 1 Table.

Yeats, R.S., and Beall, J.M., 1991, Stratigraphic controls of oil fields in the Los Angeles Basin - a guide to migration history; in Biddle, Kevin T., ed., 1991, Active Margin Basins; American Association of Petroleum Geologists Memoir 52, p. 221-237.

Yerkes, R.F., Campbell, R.H., Schoellhamer, J.E., and Wentworth, C.M., 1964, Preliminary geologic map and sections of southwest part of the Topanga quadrangle, Los Angeles County, California: U.S. Geological Survey Open-File Map, map scale 1:12,000.

Yerkes, R.F., McCulloh, T.H., Schoellhamer, J.E., and Vedder, J.G., 1965, Geology of the Los Angeles Basin, California—an introduction: U.S. Geological Survey Professional Paper 420-A, 57 p. 
Yerkes, R.F., and Campbell, R.H., 1971, Cenozoic evolution of the Santa Monica Mountains-Los Angeles Basin area, I: Constraints on tectonic models [abs.]: Geological Society of America Cordilleran Section Meeting, Abstracts with Programs, March 1971, p. 222-223.

Yerkes, R.F., Campbell, R.H., Schoellhamer, J.E., and Birkeland, P.W., 1973, Preliminary geologic map of the unincorporated part of the Topanga quadrangle, Los Angeles County, California: U.S. Geological Survey Open-File Map, map scale 1:12,000.

Yerkes, R.F., and Campbell, R.H., 1979, Stratigraphic nomenclature of the central Santa Monica Mountains, Los Angeles County, California: U.S. Geological Survey Bulletin 1457-E, p. 31 p.

Yerkes, R.F., and Campbell, R.H., 1980, Geologic map of the east-central Santa Monica Mountains, Los Angeles County, California: U.S. Geological Survey Miscellaneous Investigations Map I-1492, scale 1:24,000.

Yerkes, R.F., and Campbell, R.H., 2005, Preliminary geologic map of the Los Angeles 30’ x 60' quadrangle, southern California: U.S. Geological Survey Open-File Report 2005-1019, map scale 1:100,000, 52 p. pamphlet, chart showing correlation of map units (see http://pubs.usgs.gov/of/2005/1019/). 